\title{
Seedling Growth Performance of Four Forest Species with Different Techniques of Soil Tillage Used in Romanian Nurseries
}

\author{
Nicuşor Boja ${ }^{1}$ and Stelian Alexandru Borz ${ }^{2, *(D)}$ \\ 1 Department of Engineering and Informatics, Faculty of Economics, Informatics and Engineering, \\ "Vasile Goldiş" Western University of Arad, Liviu Rebreanu No. 86, 310414 Arad, Romania; \\ bojanicu@yahoo.com \\ 2 Department of Forest Engineering, Forest Management Planning and Terrestrial Measurements, \\ Faculty of Silviculture and Forest Engineering, Transilvania University of Braşov, Şirul Beethoven No. 1, \\ 500123 Braşov, Romania \\ * Correspondence: stelian.borz@unitbv.ro; Tel.: +40-742-042-455
}

check for updates

Citation: Boja, N.; Borz, S.A. Seedling Growth Performance of Four Forest Species with Different Techniques of Soil Tillage Used in Romanian Nurseries. Forests 2021, 12, 782. https://doi.org/10.3390/ 12060782

Academic Editor: Božena Šerá

Received: 19 April 2021

Accepted: 10 June 2021

Published: 14 June 2021

Publisher's Note: MDPI stays neutral with regard to jurisdictional claims in published maps and institutional affiliations.

Copyright: (c) 2021 by the authors. Licensee MDPI, Basel, Switzerland This article is an open access article distributed under the terms and conditions of the Creative Commons Attribution (CC BY) license (https:/ / creativecommons.org/licenses/by/ $4.0 /)$.

\begin{abstract}
Providing high quality seedlings for use in forestry applications is one of the main challenges faced by the forest nurseries, and it depends on the practices used in such facilities. For instance, controlled experiments have shown that seedling growth is affected by the soils' physical condition, which in turn is rather difficult to manipulate by the equipment used; this raises the question on whether changing the operational procedures could enable better physical properties of the seedbeds' soils, in such a way that they will contribute to a better seedling growth. This study compares two seedbed tillage systems, termed as traditional ( $T$, plowing, disk harrowing and cultivation) and minimal (M, scarifying and rototilling) in terms of physical properties of the soils and seedling growth, accounting for the variation induced by the local soil and climate conditions (three forest nurseries) as a separate factor. The results indicate highly significant gains in growth of the root collar diameter and shoot height for four tested species (pedunculate oak, common ash, wild cherry and Norway spruce), which accounted for 16 to $109 \%$ and for 10 to $134 \%$, respectively, when using the M system. Root volume growth, which was tested for pedunculate oak, has also shown significant gains, accounting for 49 to $59 \%$ as of using $\mathrm{M}$ instead of $\mathrm{T}$. In general, the seedlings resulted from the $\mathrm{M}$ treatment were found to be more homogeneous in terms of morphological characteristics, though the association and dependence between their features and physical properties of the soils were poorer. These gains in growth seem to be more related to the tillage systems rather than to local soil and climate conditions, as no or marginally significant differences were found to support their relation to the forest nurseries taken into study. The main conclusion of the study is that changing the regular seedbed tillage system by the minimal one could contribute not only at improving the growth of the seedlings, but also to the responsivity of forest nurseries.
\end{abstract}

Keywords: forest nurseries; seedbed treatments; mechanization level; soil; physical properties; seedling; growth; association; dependence; improvement

\section{Introduction}

Forests provide a wide range of ecosystem services, contributing to the wellbeing of people and to the development of human society. Planting new forests and restocking the harvested areas are well established practices that support the extension and regeneration of forest ecosystems, and which are also expected to contribute to forest restoration initiatives throughout the world [1]. Seedling planting is one of the commonly used methods to establish or regenerate forests [2], being used to various spatial extents and temporal frames, and implemented by various means and procedures, depending on many factors such as the type of forest management, forest type and climate, local topography, soil 
condition and forest accessibility, mechanization level, manual labor availability, local practices and scientific developments [3-19].

Successful planting operations require seedlings able to survive and develop by growth in various environmental conditions, and depend largely on the seedling quality and site conditions, a reason for which the two need to be evaluated and carefully balanced [3]. As seedlings are commonly grown in forest nurseries, the operations which are carried out to produce them need to be done sustainably. This means, among other things, that seedlings need to be produced and delivered in due time, at the required quantity and quality, at minimal costs and environmental impact, and with minimal input of resources, a view which is consistent with the most recent concept of sustainable forest operations [20]; similar to forest operations, research on the topic should be focused on developing knowledge to support the practice and its improvement [21]. Seedling quality is often evaluated by a set of morphological and physiological traits which, when provided in an optimal range, are assumed to contribute to the success of planting applications, where the latter is often characterized in terms of outcomes such as the seedling survival and growth. Review studies have indicated that morphological features such as the shoot height, root collar diameter, root system and shoot-to-root ratio, play a central role in both seedling survival and growth after outplanting $[22,23]$. For instance, in the case of planting sites in which the seedlings are not subjected to an excessive environmental stress, survival was found to be enhanced when seedlings are characterized by higher shoot heights, root collar diameters, and well-developed root systems [22]; accordingly, the review of Grossnickle and MacDonald [23], has indicated that seedling features such as a higher shoot height and root collar diameter, a well-developed root system and a low shoot-to-root ratio are contributors to seedling growth enhancement after planting.

Most of the morphological features that seedlings should have when released for different applications are developed by implementing a set of nursery operations. Acknowledging the effects that other factors may have, the quality of the soil before sowing is, perhaps, one of the most important factors affecting the development of seedlings' morphological features. This is because, in general, the available spaces in the soil affect water infiltration, atmosphere composition and penetration by roots, while an increased bulk density of the soil is unfavorable to root development opposing a higher resistance against root penetration [24], which, in turn, will affect the plant nutrition and growth processes. For instance, recent work developed under controlled conditions to check the oak seedlings' growth as a response to various soil compaction levels has shown that the length developed by the main root was affected by soil compactness level [25]. However, seedlings belonging to different species seem to behave differently when exposed to different levels of soil compactness, with some exhibiting no measurable growth, while other react by positive or negative responses [26].

Typically, the quality of the seedbeds, which is reflected by the physical properties of the soils embodied in them, is related to the soil tillage practices, as specific to different forest nurseries. The type of operations and machines used to prepare the seedbeds, on the other hand, may depend largely on the economic context of the forest nurseries, which may be a function of nursery's scale and local economy. As such, most of large-scale, commercial nurseries, located in developed countries, have been commonly equipped with purpose-built machines [27], which have been significantly improved over time. However, small- to medium scale nurseries located in countries under development are typically reflecting the general context found, for instance, in harvesting operations [28], which may be characterized by the use of rather obsolete technology, in the form of general-purpose agricultural equipment and an intensive use of manual labor. This is quite specific to Romania, where most of the forest nurseries are likely to be established at a rather small scale. For instance, the Romanian literature categorizes such facilities as being small when having less than 1 ha (cultivation of coniferous and at most $20 \%$ broadleaved seedlings), 3 ha (cultivation of coniferous and broadleaved seedlings) and 5 ha (cultivation of broadleaved and at most $20 \%$ coniferous seedlings), respectively [3]. 
As of 2019, there was a number of 1165 forest nurseries managed by the National Forest Administration established on a total area of ca. 1690 ha [29], indicating an average area per nursery of less than $1.5 \mathrm{ha}$. In addition, the commonly used (traditional) system to prepare the seedbeds has been that consisting of three operational steps, namely plowing, disk harrowing, and cultivation, which has been enabled by the existence of equipment typically used in agricultural operations. Although the use of similar systems was documented also internationally [30], in the meantime, alternative equipment such as that enabling soil scarifying (chisel plowing) and rototillers [31] was purchased and used in various types of forest operations, a choice which was probably based on informal knowledge. However, the benefits brought by its use, as compared to the traditional alternatives, have rarely been evaluated scientifically, being rather embodied in the tacit experience of the practice.

Based on the above, the idea of comparatively testing the traditional and newgeneration equipment has emerged to document the benefits, if any, that could be brought to forest nurseries by changing the seedbed tillage system in use with a new one, assumed to be able to provide improved conditions for seedling growth and development. As such, this study aimed at comparing two field seedbed tillage systems, namely the soil plowing, disk harrowing and cultivation, which is referred hereafter as the "traditional system- $\mathrm{T}$ " and the soil scarifying-rototilling, which is referred hereafter as the "minimal system-M". While this study deals with the changes that the two mechanized systems could bring to the soils' physical properties, the comparison approach was threefold. Accordingly, the objectives of this study were set to: (i) checking which of the two systems would perform better in terms of seedling growth, by taking into consideration four of the species commonly grown as seedlings in the Romanian forest nurseries (ii) checking how and which of the soil physical properties following the seedbed tillage operations were related to the seedling growth, and (iii) checking if the two systems will perform similarly in terms of seedling development and growth, irrespective of the soil type and local climate.

\section{Materials and Methods}

\subsection{Description of Forest Nurseries and Local Conditions}

Three forest nurseries were selected in the western part of Romania to carry on the experiments of this study (Table 1, Figure 1), as being representative for the Romanian conditions in respect to their size and, to some extent, to their topography-based distribution and local climate.

Table 1. Location of the forest nurseries and main description of the sites.

\begin{tabular}{|c|c|c|c|c|c|c|}
\hline Nursery & Abbreviation & Location & $\begin{array}{l}\text { Altitude } \\
\text { (m, a.s.1.) }\end{array}$ & Aspect & Area (ha) & Soil Taxonomy \\
\hline Iarac & FN1 & $\begin{array}{l}46^{\circ} 09^{\prime} 35.4^{\prime \prime} \mathrm{N} \\
21^{\circ} 16^{\prime} 36.0^{\prime \prime} \mathrm{E}\end{array}$ & 100 & Northeastern & 2.20 & Fluvisol \\
\hline Agrişul Mare & FN2 & $\begin{array}{l}46^{\circ} 16^{\prime} 40.5^{\prime \prime} \mathrm{N} \\
21^{\circ} 45^{\prime} 59.6^{\prime \prime} \mathrm{E}\end{array}$ & 175 & Northeastern & 5.40 & Luvisol \\
\hline Iosăşel & FN3 & $\begin{array}{l}46^{\circ} 18^{\prime} 27.7^{\prime \prime} \mathrm{N} \\
22^{\circ} 21^{\prime} 29.5^{\prime \prime} \mathrm{E}\end{array}$ & 380 & Northeastern & 1.20 & Cambisol \\
\hline
\end{tabular}

The forest nursery of Iarac, hereafter FN1, is located in the steppe vegetation zone on a fluvisol, being characterized by a mean precipitation level of $550 \mathrm{~mm} \times \mathrm{y}^{-1}$, and an average annual temperature of $10.8^{\circ} \mathrm{C}$. The forest nursery of Agrişul Mare, hereafter FN2, is located in the plain forested zone on a luvisol, being characterized by a mean precipitation level of $750 \mathrm{~mm} \times \mathrm{y}^{-1}$ and an average yearly temperature of $10.0^{\circ} \mathrm{C}$. Finally, the forest nursery of Iosăşel, hereafter FN3, is located in the hilly forested zone on a cambisol, being characterized by a mean precipitation level of $1000 \mathrm{~mm} \times \mathrm{y}^{-1}$ and an average yearly temperature of $7.5^{\circ} \mathrm{C}$. According to the Köppen classification, the climate of the area is included in the C.f.a.x (FN1) and C.f.b.x (FN2 and FN3) zones, being characterized by an average temperature of the warmest month higher than $10^{\circ} \mathrm{C}$, a rainy climate and 
warm winters, with sufficient precipitations throughout the year, and maximum and minimum precipitation amounts recorded at the beginning and end of the summer and winter, respectively [32].

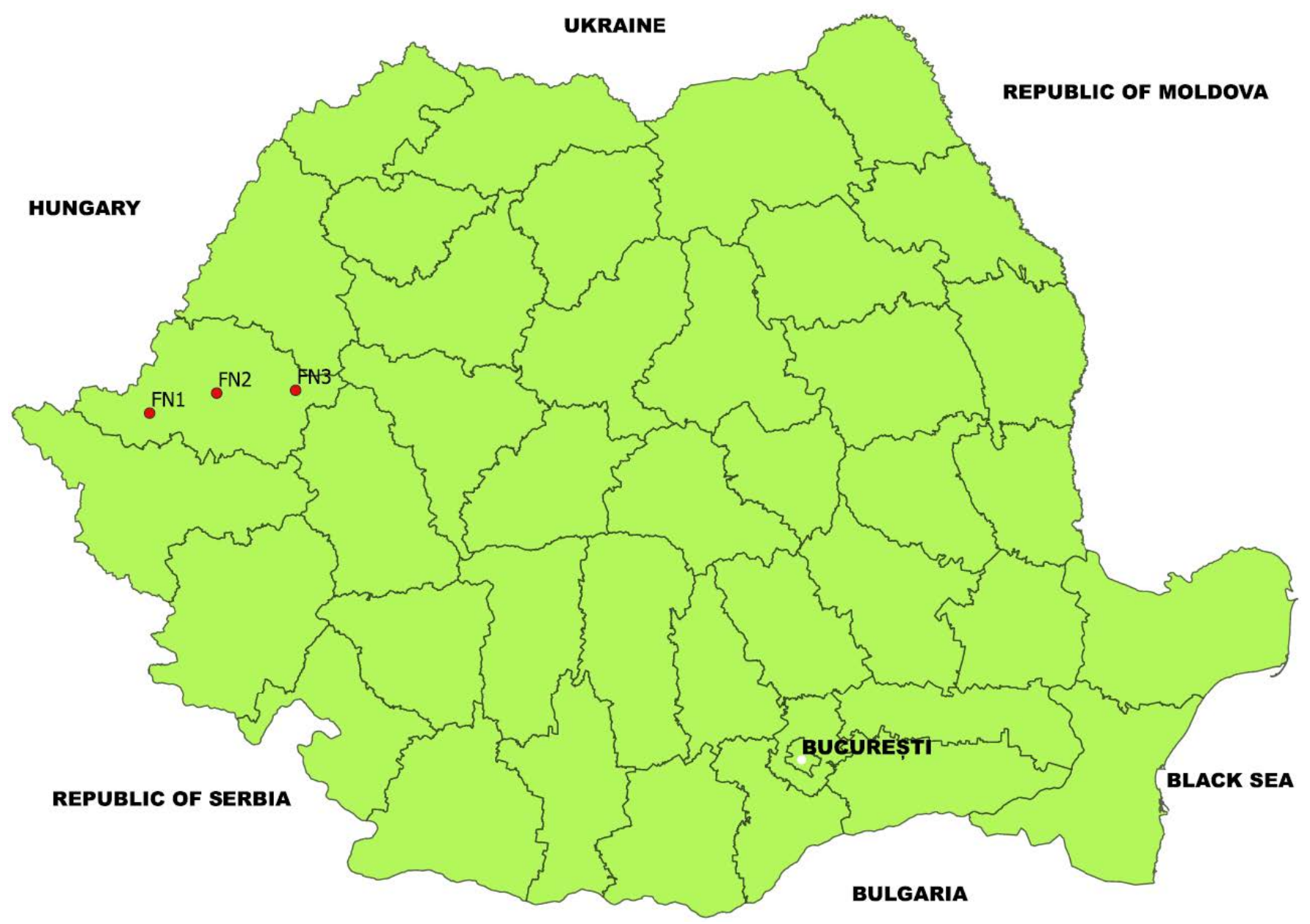

Figure 1. Map of the Romania showing the locations of the forest nurseries taken into study.

Initially, the soils were documented from the corresponding forest management plans to have an idea on the existing soil type in each forest nursery. According to the description of the forest soils given in [33], fluvisols are characterized as being young soils accumulating fluvial, lacustrine or marine deposits, luvisols are characterized by a higher clay content in the subsoil, high-activity clays in the argic horizon and a high saturation in bases at the 50-100 cm in depth, and cambisols show at least an incipient subsurface soil formation, with an evident transformation of parental material and increased clay percentage and carbonate removal. Prior to the field experiments, and after them, detailed laboratory analyses were conducted at the soil testing laboratory of the Agricultural Directorate of Arad (Romania), having as a reference the procedures outlined in [34,35]. The procedures used for field sampling are described in the field data collection section of this paper, while the outcomes of the initial soil analysis are given in the Appendix A section (Tables A1 and A2).

\subsection{Description of Seedbed Tillage Systems}

Two seedbed tillage systems were used as a reference for comparison in this study (Table 2, Figure 2). The traditional system (T), consisted of using a $47.8 \mathrm{~kW}$ tractor (Model U650, Braşov, Romania,) equipped successively with a plow (Model PP-3-30-M), a disk harrow (Model GD-4) and a cultivator (Model CPU-4.2). The practice has shown that the implementation of this operational sequence is required, in general, due to the poorer qual- 
ity of the seedbed which could be achieved only by implementing the first two operations. As such, this system requires three passes on the same area (Table 2). The minimal seedbed tillage system $-\mathrm{M}$, (Table 2, Figure 2) consisted of the use of a John Deere tractor (Model JD 8400), which was equipped with a scarifier (model Artiglio, Maschio Gaspardo Romania, Chişineu-Criş, Romania) and then with a rototiller (model AZ 145 C, Maschio Gaspardo Romania, Chişineu-Criş, Romania). In this configuration, two passes were required to prepare the seedbeds.

Table 2. Description of the equipment used in the two seedbed tillage systems.

\begin{tabular}{ccccc}
\hline $\begin{array}{c}\text { Seedbed Tillage } \\
\text { System }\end{array}$ & $\begin{array}{c}\text { System } \\
\text { Abbreviation }\end{array}$ & Equipment & $\begin{array}{c}\text { Number of } \\
\text { Passes }\end{array}$ & $\begin{array}{c}\text { Operated } \\
\text { Depth (cm) }\end{array}$ \\
\hline Traditional & $\mathrm{T}$ & Tractor + Plow + Disk Harrow + Cultivator & 3 & 30 \\
Minimal & $\mathrm{M}$ & Tractor + Scarifier + Rototiller & 2 & 50 \\
\hline
\end{tabular}

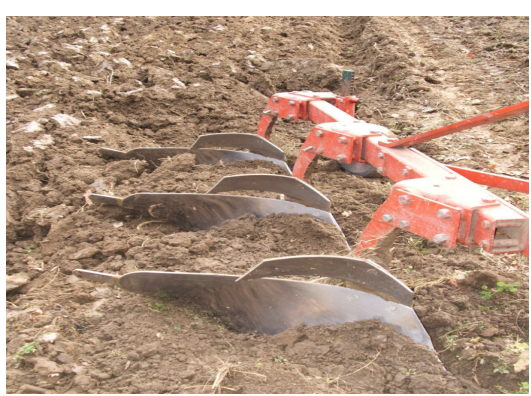

1

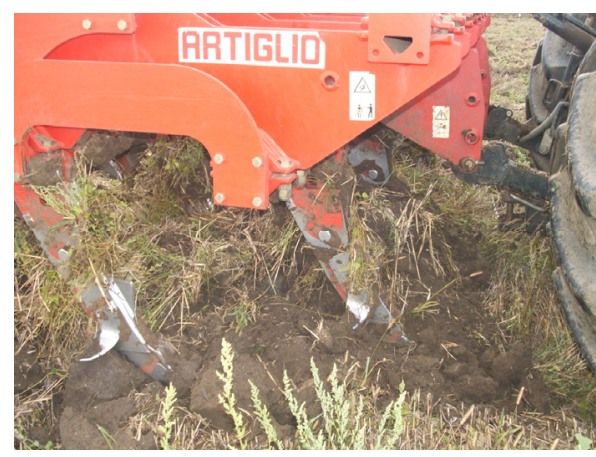

1

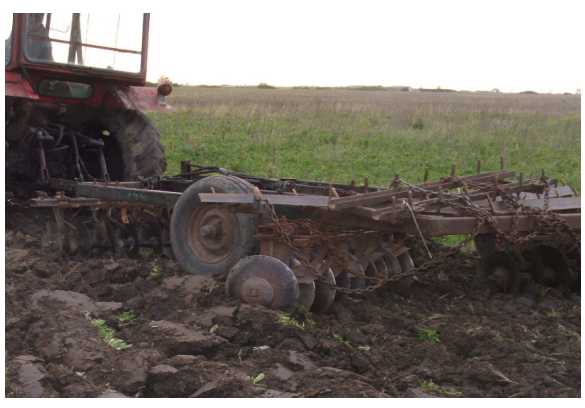

2

(a)

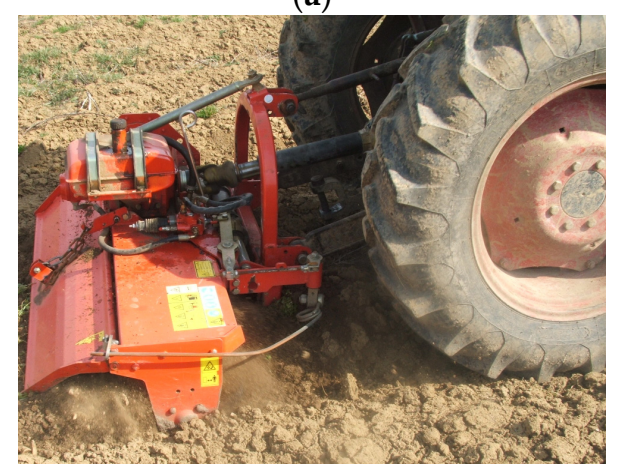

2

(b)

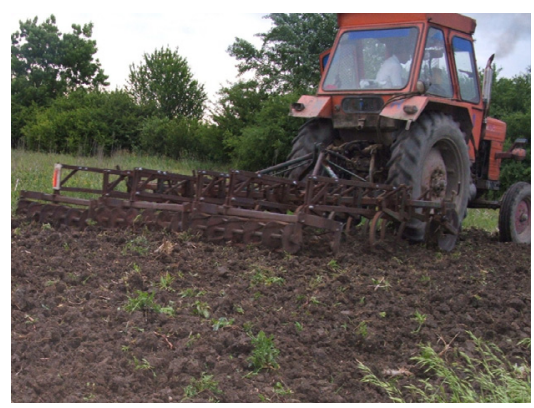

3

Figure 2. Description of the equipment used in the traditional (a) and minimal (b) seedbed tillage systems. Legend: (a) - traditional seedbed tillage system: 1-plow, 2-disk harrow, 3-cultivator; (b)-minimal seedbed tillage system: 1-scarifier, 2-rototiller.

In addition to their main description, there are also other important features of the studied systems. For instance, $\mathrm{T}$ is able to implement soil tillage operations up to a depth of $30 \mathrm{~cm}$, while $\mathrm{M}$, by the use of the scarifier, is able to implement such operations up to a depth of $50 \mathrm{~cm}$. Accordingly, the second system holds the capability to provide a deeper soil operation. The sizes of the plots on which the two systems were implemented in each forest nursery were correlated with the number of seedling species produced and observed during the tests (see Section 2.4.1. for more details). 


\subsection{Species Used, Sowing and Cultural Operations}

Seedlings belonging to four species are commonly grown in the forest nurseries taken into study. Typically, in FN1 are grown seedlings of pedunculate oak (Quercus robur L.) and common ash (Fraxinus excelsior L.), while in FN2, wild cherry (Prunus avium L.) is cultivated in addition to pedunculate oak. Finally, in FN3 are grown seedlings of pedunculate oak and Norway spruce (Picea abies L. Karst). Irrespective of the forest nursery, sowing was done directly in the nurseries' fields in the autumn of 2016 (pedunculate oak, common ash and wild cherry), at a depth of 5 to $8 \mathrm{~cm}$, in twin rows spaced at $15 \mathrm{~cm}$, by preserving a distance of $60 \mathrm{~cm}$ between them. Norway spruce seedlings were grown in a greenhouse for one year and transplanted in the nursery field at the same time with the rest of the species and by using the same spacing. The used seeds were procured from the nearby forest districts, from forest stands specially designated for seed production. Regular treatments were applied to the seeds before sowing (e.g., seeds of wild cherry were treated by diluted copper sulphate and seeds of common ash were stratified); then fertilizes were administrated to all the plots accounting for $200 \mathrm{~kg}$ of NPK (16-16-16) complex per hectare, administered on the snow layer, and $100 \mathrm{~kg}$ of nitrogen (urea, soluble in water, content in nitrogen of up to $46 \%$ ) per hectare, administrated after sprouting. A number of seven manual cultivation operations were carried out in each forest nursery and for each species and seedbed tillage system, which covered the time from sowing (transplanting) to seedling measurement, and irrigation operations were done when necessary.

\subsection{Data Collection}

\subsubsection{Designation of Control and Test Plots}

Table 3 shows a summary description of the experimental layout in relation to the two tested seedbed tillage systems. Plots of 0.4 ha in size were designated in each forest nursery, which were used to get the data needed for testing the effects of the two seedbed tillage systems in terms of growth measured by the root collar diameter and shoot height; by this kind of plot designation, the intention was to account for each species under study, in a comparison approach which was refrained to the effect of the seedbed tillage system. As such, in FN1, were designated four plots of which two for pedunculate oak and two for common ash, in FN2 were designated two plots for wild cherry and in FN3 were designated two plots for Norway spruce. For each species, one plot was prepared by implementing the $\mathrm{T}$ (traditional) system and the other by implementing the $\mathrm{M}$ (minimal) system.

Table 3. Description of experimental layout for comparing the effect of the seedbed tillage system on seedling growth at species level.

\begin{tabular}{|c|c|c|c|c|c|}
\hline $\begin{array}{c}\text { Forest } \\
\text { Nursery }\end{array}$ & $\begin{array}{c}\text { Seedbed Tillage } \\
\text { System } \\
\text { (Abbreviation) }\end{array}$ & $\begin{array}{l}\text { Area } \\
\text { (ha) }\end{array}$ & $\begin{array}{c}\text { Plot Type } \\
\text { (Species abbreviation) }\end{array}$ & Purpose for the Study & $\begin{array}{c}\text { Treatment } \\
\text { Abbreviation }\end{array}$ \\
\hline \multirow{5}{*}{$\begin{array}{c}\text { FN1 } \\
\text { (Iarac) }\end{array}$} & Traditional (T) & 0.4 & Pedunculate oak $(\mathrm{O})$ & Soil changes \& effect on growth & FN1TO \\
\hline & Minimal (M) & 0.4 & Pedunculate oak $(\mathrm{O})$ & Soil changes \& effect on growth & FN1MO \\
\hline & Traditional (T) & 0.4 & Common ash (A) & Soil changes \& effect on growth & FN1TA \\
\hline & Minimal (M) & 0.4 & Common ash (A) & Soil changes \& effect on growth & FN1MA \\
\hline & Control (C) & 0.2 & Empty & Soil changes & FN1C \\
\hline FN2 & Traditional (T) & 0.4 & Wild cherry (C) & Soil changes \& effect on growth & FN2TC \\
\hline (Agrişul & Minimal (M) & 0.4 & Wild cherry (C) & Soil changes \& effect on growth & FN2MC \\
\hline Mare) & Control (C) & 0.2 & Empty & Soil changes & FN2C \\
\hline \multirow{3}{*}{$\begin{array}{c}\text { FN3 } \\
\text { (Iosăşel) }\end{array}$} & Traditional (T) & 0.4 & Norway spruce (S) & Soil changes \& effect on growth & FN3TS \\
\hline & Minimal (M) & 0.4 & Norway spruce (S) & Soil changes \& effect on growth & FN3MS \\
\hline & Control (C) & 0.2 & Empty & Soil changes & FN3C \\
\hline
\end{tabular}

To check the differences in terms of root system size and those which could be brought by the use of a given seedbed tillage system irrespective of the forest nursery, two comparative plots were selected in each forest nursery (description not shown in Table 3), which 
were operated by implementing the traditional and minimal systems, respectively. These plots were designated for oak seedlings and they served for a comparative analysis of the root system size. For soil sampling, testing and comparison purposes one unprepared plot of 0.2 ha was designated in each forest nursery and labelled as C (control).

\subsubsection{Shoot Size, Root Collar Diameter and Root System Size}

While there are many parameters which can be used to characterize the growth and development of the seedlings, in this study the choice was to account for those easy to measure by general, non-destructive methods. For each test plot described in Table 3, a row of seedlings was randomly chosen and fully inventoried to measure the shoot height $(\mathrm{H})$ and the root collar diameter (D) of each individual.

Field measurements were done at the middle of the growing season (May of 2017) by using a high precision caliper and a graded tape. Root collar diameter was measured to the nearest micron and shoot height was measured to the nearest centimeter. In total, 1072 seedlings (342 of oak, 292 of ash, 292 of cherry and 146 of spruce) were measured for each seedbed tillage system $(2 \times 1072)$ by the approach described above, using as a guideline the work of [2], and the relevant data was noted on a field book.

Based on existing knowledge on the specific growth and root development, seedlings of pedunculate oak were selected for evaluating the size of the root system as this species is known to invest in developing a main root [36]. In this case, the aim was to design balanced treatments while keeping the sample sizes at the minimum to prevent unnecessary seedling losses; therefore, a number of 35 seedlings were systematically extracted from each seedbed treatment and from each forest nursery (210 seedlings in total) by a design which aimed at sampling on the plots' diagonals; 17 individuals were extracted on each diagonal of a given plot and one individual was extracted from each plot's center.

Extraction was done in October of 2017, by a careful excavation so as not to alter the roots of the sampled seedlings, then the roots of the sampled individuals were carefully washed in a low water flow until removing all the soil from the roots. After a short-term drying at the room temperature, the root volume was measured for each individual to the nearest cubic centimeter by the use of the water displacement method and graded cylindrical glasses; following the measurements, the sampled seedlings were planted.

\subsubsection{Soil Samples}

Soil samples were taken by a multilayered design, accounting for the first $30 \mathrm{~cm}$ of the soil (Table 4), and for a sampling procedure that has used the diagonals of each plot. For doing so, pits were manually dug at approximate dimensions of $30 \mathrm{~cm} \times 30 \mathrm{~cm} \times 30 \mathrm{~cm}$, and were considered hereafter as sampling units, then samples were collected from each pit at depths (soil layers) of 0 to 5,5 to 10, 10 to 20 and 20 to $30 \mathrm{~cm}$. By design, a number of 4 samples were taken from each pit, by configuring a number of 3 pits on each plot's diagonal, following each operation of a given seedbed tillage system.

Steel cylinders were used to collect the samples by placing them at the middle of each layer and by inserting them into the soil using a hammer. Following the extraction, the soil samples were stored in plastic bags along with a descriptive label indicating their plot, pit (sampling unit), relative position on the pits' depth and the operation type to which they belonged.

Table 4 shows the details of the design used to collect the soil samples. As shown, a number of 108 soil sampling units (pits) were used to collect a number of 432 soil samples, following a design able to characterize the changes induced by each operation of the tested seedbed tillage systems and to compare such changes to the condition of unoperated soil.

In addition to the sampling design described in Table 4, which was related to the main comparison requirements of the study, prior to the implementation of the experiments, one sampling unit was designated in each forest nursery, from which soil samples were taken at depths of 0 to 10, 10 to 20 and 20 to $30 \mathrm{~cm}$. These soil samples served as a reference for analysing the soils in terms of particle size distribution and chemical properties. Sampling procedures were similar to those described above. 
Table 4. Design of the soil sampling procedures.

\begin{tabular}{|c|c|c|c|c|c|c|c|c|}
\hline Nursery & $\begin{array}{l}\text { Seedbed Tillage } \\
\text { System } \\
\text { (Abbreviation) }\end{array}$ & $\begin{array}{c}\text { Total } \\
\text { Number of } \\
\text { Sampling } \\
\text { Pits }\end{array}$ & $\begin{array}{c}\text { Before } \\
\text { Operations } \\
\text { (Pits) }\end{array}$ & $\begin{array}{l}\text { After } \\
\text { Plowing } \\
\text { (Pits) }\end{array}$ & $\begin{array}{l}\text { After } \\
\text { Disking } \\
\text { (Pits) }\end{array}$ & $\begin{array}{l}\text { After Culti- } \\
\text { vation } \\
\text { (Pits) }\end{array}$ & $\begin{array}{c}\text { After } \\
\text { Scarifying } \\
\text { (Pits) }\end{array}$ & $\begin{array}{c}\text { After } \\
\text { Rototilling } \\
\text { (Pits) }\end{array}$ \\
\hline \multirow{3}{*}{$\begin{array}{l}\text { FN1 } \\
\text { (Iarac) }\end{array}$} & Traditional (T) & 18 & - & 6 & 6 & 6 & - & - \\
\hline & Minimal (M) & 12 & - & - & - & - & 6 & 6 \\
\hline & Control (C) & 6 & 6 & - & - & - & - & - \\
\hline FN2 & Traditional (T) & 18 & - & 6 & 6 & 6 & - & - \\
\hline (Agrişul & Minimal (M) & 12 & - & - & - & - & 6 & 6 \\
\hline Mare) & Control (C) & 6 & 6 & - & - & - & - & - \\
\hline \multirow{3}{*}{$\begin{array}{c}\text { FN3 } \\
\text { (Iosăşel) }\end{array}$} & Traditional (T) & 18 & - & 6 & 6 & 6 & - & - \\
\hline & Minimal (M) & 12 & - & - & - & - & 6 & 6 \\
\hline & Control (C) & 6 & 6 & - & - & - & - & - \\
\hline
\end{tabular}

Soil analysis tasks were carried out at the accredited soil testing laboratory of the Agricultural Directorate of Arad (Romania) and, in addition to the granulometric and chemical analysis of non-operated soil samples, they aimed at determining the relevant physical properties $[34,35]$ following given operations such as the soil's bulk density $\left(\mathrm{g} \times \mathrm{cm}^{-3}\right)$, moisture content $(\%)$, porosity $(\%)$, water stock $\left(\mathrm{m}^{3} \times \mathrm{ha}^{-1}\right)$ and the degree of soil compactness (\%).

\subsection{Data Processing and Statistical Analysis}

\subsubsection{Data Processing}

Data characterizing the root collar diameter and shoot height was transferred from the field book into a Microsoft Excel ${ }^{\circledR}$ (Microsoft, Redmond, WA, USA) database, where it was organized on the described treatments, accounting for the seedbed tillage system and species under comparison. A similar procedure was used for the data characterizing the root volume, which was organized at nursery and seedbed tillage system levels. Separate databases were developed for the characteristics of the soils. Following the laboratory analysis, data from the test plots was summarized to account for the soil's physical properties, forest nursery, soil depth, treatment and seedbed tillage operation. Data from the control plots was organized in a similar way and the data on soil samples collected before the implementation of the experiments was organized to support the analysis of soils' particle size distribution and chemical properties.

\subsubsection{Statistical Analysis}

Statistical analysis was guided by the objectives of the study. A first step was to check the datasets characterizing each variable for normality by implementing a Shapiro-Wilk test. Then, the main descriptive statistics, such as the mean value and standard deviation were computed for each dataset. Depending on the outcome of normality check, parametric and nonparametric comparison tests and multifactorial statistical designs were used to check the differences between the variables. Since the root collar diameter and shoot height were found to fail the normality check, the statistical comparisons of these variables, aiming at checking the effect of the seedbed tillage system on the seedling growth, were done by the use of the Mann-Whitney nonparametric test. Root system size and soil's physical characteristics, on the other hand, were found to pass the normality check. As such, parametric two-tailed Student's $t$ and ANOVA tests were used for these variables to check the differences induced by the seedbed tillage system and forest nursery.

Relations between the changes in the soils' physical properties and the growth of the seedlings (root collar diameter, shoot height and root volume) were checked by running pairwise correlation and linear regression analyses. They used the mean values characterizing the seedling growth as response variables and the mean values characterizing the soil physical characteristics, and they were implemented at the sampled soil layers' 
level. The choice of these statistical techniques was mainly based on the limited amount of information reflected by the number of observations available as mean values. As such, the final outcomes in terms of seedbed tillage system (physical properties following the implementation of the final operation as specific to each seedbed treatment) were selected either as variables used in the correlation analysis or as explanatory variables used in the linear regression analysis.

Similarity in terms of growth and development of the seedlings as an effect of the seedbed tillage system was evaluated by the use of a hierarchical cluster analysis. The mean values of the root collar diameter, shoot height and root volume were used successively as target variables which were clustered based on the layer-level physical characteristics of the soils. The complete-linkage procedure was used to cluster the data, which was based on the Euclidian distance metric. Following hierarchical clustering, silhouette plots based on cosine distance were used as a mean of interpretation and validation of clusters' consistency.

The statistical analysis aiming to check for normality, develop the descriptive statistics, including the associated artwork, and to make statistical comparisons was run in Microsoft Excel ${ }^{\circledR}$ fitted with the freeware Real Statistics add-in (https:/ / www.real-statistics.com/, accessed on 1 April 2021). The significance testing was done for a confidence threshold of $95 \%(\alpha=0.05, p<0.05)$. Hierarchical cluster analysis was done by the means of the Orange Visual Programming ${ }^{\circledR}$ software, v3.2.7.1 [37], which was fed with databases prepared as Microsoft Excel files.

\section{Results}

\subsection{Seedling Growth}

\subsubsection{Shoot Length and Root Collar Diameter}

The results describing the growth of the seedlings in terms of shoot size and root collar diameter are given, by a comparative approach, in Table 5. They are generally indicating that the growth of the seedlings was significantly $(\alpha=0.05, p<0.01)$ affected by the type of the used seedbed tillage system.

Table 5. Descriptive statistics and comparison tests of the shoot length and rood collar diameter.

\begin{tabular}{|c|c|c|c|c|c|c|c|c|}
\hline $\begin{array}{l}\text { Treatment } \\
\text { Abbrevia- } \\
\quad \text { tion }\end{array}$ & $\begin{array}{l}\text { Root } \\
\text { Collar } \\
\text { Diameter } \\
(\mathrm{mm})^{1}\end{array}$ & $\begin{array}{l}\text { Shoot Height } \\
\quad(\mathrm{cm})^{1}\end{array}$ & $\begin{array}{c}\text { Diameter's } \\
\text { Coefficient } \\
\text { of Variation } \\
(\%)\end{array}$ & $\begin{array}{c}\text { Height's } \\
\text { Coefficient } \\
\text { of Variation }\end{array}$ & $\begin{array}{c}\text { Height to } \\
\text { Diameter } \\
\text { Ratio }\end{array}$ & $\begin{array}{l}\text { Diameter } \\
\text { Gain (\%) }\end{array}$ & $\begin{array}{l}\text { Height } \\
\text { Gain } \\
(\%)\end{array}$ & $\begin{array}{l}\text { Comparison } \\
\text { Diagnose }^{2}\end{array}$ \\
\hline FN1TO & $2.12(1.03)$ & $10.64(2.71)$ & 48.62 & 25.51 & 5.0 & & & $\mathrm{D}\left({ }^{* * *}\right)$ \\
\hline FN1MO & $3.63(1.52)$ & $22.25(6.06)$ & 41.85 & 27.24 & 6.1 & +71 & +109 & $\left.\mathrm{H}^{(* * *}\right)$ \\
\hline FN1TA & 5.75 (1.35) & $25.18(5.12)$ & 23.55 & 20.33 & 4.4 & & & $\mathrm{D}\left({ }^{* * *}\right)$ \\
\hline FN1MA & $7.53(1.88)$ & $43.66(12.18)$ & 25.00 & 27.90 & 5.8 & +31 & +73 & $\mathrm{H}\left({ }^{* * *}\right)$ \\
\hline FN2TC & $1.84(1.18)$ & $19.04(5.79)$ & 64.13 & 30.40 & 10.3 & & & $\mathrm{D}\left({ }^{* * *}\right)$ \\
\hline FN2MC & $4.32(1.27)$ & $22.88(6.26)$ & 29.53 & 27.37 & 5.3 & +134 & +20 & $\mathrm{H}\left({ }^{* * *}\right)$ \\
\hline FN3TS & $4.12(1.25)$ & $21.25(6.30)$ & 30.27 & 29.63 & 5.2 & & & $\mathrm{D}^{(* *)}$ \\
\hline FN3MS & $4.52(1.28)$ & $24.59(5.85)$ & 28.31 & 23.78 & 5.4 & +10 & +16 & $\mathrm{H}\left({ }^{* * *}\right)$ \\
\hline
\end{tabular}

Notes: ${ }^{1}$ Values given in the brackets stand for the standard deviation, while the rest stand for the mean value; ${ }^{2}$ Diagnoses indicated by ** stand for $p$ values in the range of 0.01 to 0.001 , while diagnoses indicated by *** stand for $p$ values less than 0.001 . Note: in most of the cases, the data on root collar diameters and shoot heights failed normality checks, therefore Mann-Whitney tests were used for comparison.

By the use of the Mann-Whitney's test, the shoot height (H, Table 5), for instance, was found to differ very significantly irrespective of the species ( $p$ values close to 0 in all the compared pairs, data not given herein). This outcome was found to be generally specific also in the case of the root collar diameter (D, Table 5), where only in the case of the Norway spruce seedlings the significance values $(\mathrm{p}$ ) were in the range of 0.001 to 0.01 . Comparison of the growth parameters has indicated noticeable differences in all the compared pairs. For instance, the growth gain in terms of root's collar diameter as of using the M instead of the $\mathrm{T}$ seedbed tillage system was of $10 \%$ for spruce seedlings, but it reached to more than $130 \%$ for wild cherry seedlings. Accordingly, the gains in shoot height were in range 
of 16 (Norway spruce) to 109\% (pedunculate oak). Ratio of the shoot height to the root's collar diameter was higher in all the cases where the M seedbed tillage system was used, excepting the case of wild cherry, where this parameter was affected by a stronger growth in diameter as compared to the growth in height. Following the implementation of the two seedbed tillage systems, the variation of morphological features (shoot height and root collar diameter), evaluated by the means of the coefficient of variation (Table 5), tended to be less as an outcome of using the M system, indicating therefore a higher growth uniformity in this latter case.

\subsubsection{Root Volume}

Differences in terms of root volume were evident between the two treatments taken into study (T-traditional vs. M-minimal, Figure 3). As a fact, and depending on the forest nursery, the root volume of the pedunculate oak seedlings was by ca. 49 (FN3) to $59 \%$ (FN1) higher as a result of implementing the M system (results not reported herein). From a statistical point of view, very significant differences $(\alpha=0.05, p<0.001)$ were found between the two treatments irrespective of the forest nursery taken into consideration. Unlike the case of the shoot size and of the root collar diameter, the data characterizing the root volume has shown similar coefficients of variation irrespective of the treatment, which were in the range of ca. 20 to 23 (detailed data not shown herein). It is evident, therefore, that the implementation of $\mathrm{M}$ system has led to a better development of the root systems.

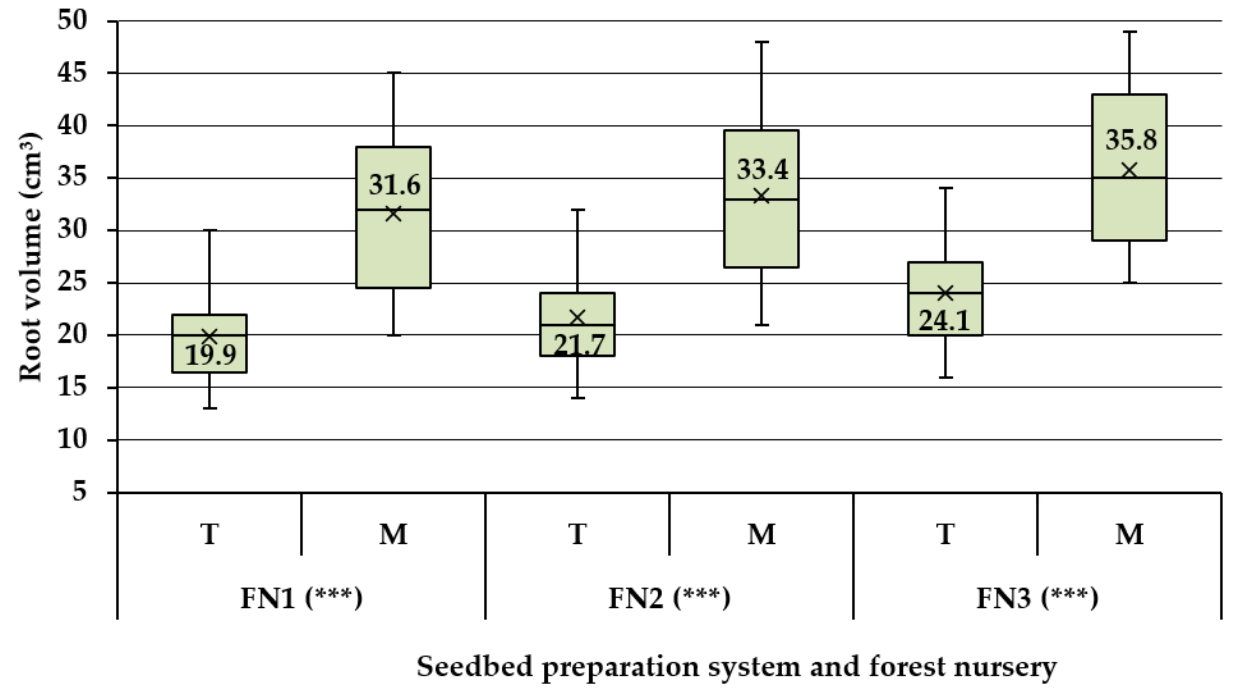

Figure 3. Descriptive statistics and results of the statistical comparison of root's volume at the forest nursery level. Legend: $\mathrm{T}$-traditional seedbed tillage system, $\mathrm{M}$-minimal seedbed tillage system, FN1-forest nursery of Iarac, FN2 - forest nursery of Agrişul Mare, FN3 - forest nursery of Iosăşel. Note: diagnose indicated by ${ }^{* * *}$ stands for $p$ values less than 0.001 .

Results of the ANOVA test done on the data characterizing the M seedbed tillage system have indicated no significant statistical differences in terms of root volume as potentially induced by the specificity of the three nurseries taken into study (Figure 4). Given these statistical outcomes, no further statistical tests were carried out to compare potential pairwise differences between the root volumes as outcomes specific to each of the three forest nurseries. Nevertheless, it is worth to mention that there were differences in size which accounted for ca. 5.6\% between FN2 and FN1, 13.3\% between FN3 and FN1 and $7.2 \%$ between FN3 and FN2. The situation was different in the case of T seedbed tillage system, because the results of ANOVA test proved to be significant, indicating therefore differences in terms of root volume as an effect of the forest nursery taken into study. In this case, the percentual differences, in the same order as given before, accounted for ca. 9, 21 and $9 \%$, respectively. 


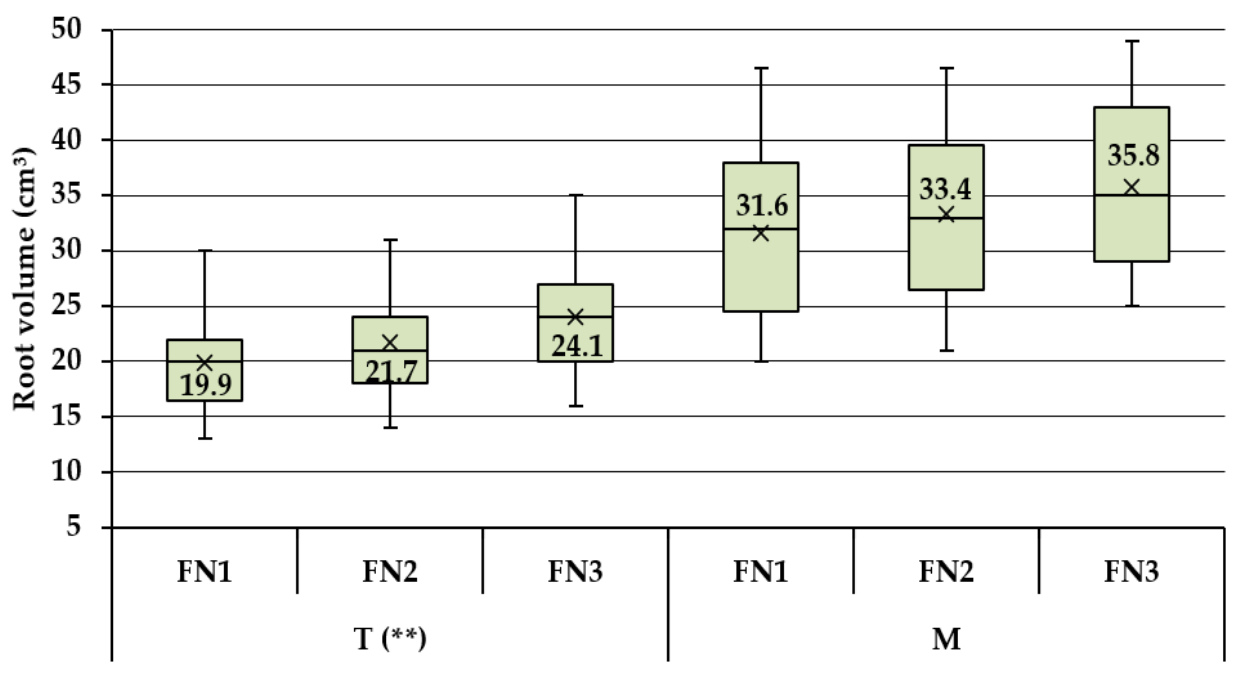

Forest nursery and soil preparation system

Figure 4. Descriptive statistics and results of the statistical comparison of root's volume at the seedbed tillage system level. Legend: $\mathrm{T}$ - traditional seedbed tillage system, $\mathrm{M}$-minimal seedbed tillage system, FN1—forest nursery of Iarac, FN2—forest nursery of Agrişul Mare, FN3—forest nursery of Iosăşel. Note: diagnose indicated by ** stands for $p$ values in the range of 0.01 to 0.001 .

Given the results of the statistical tests, one can infer that the $\mathrm{M}$ system was able to provide relatively the same root development opportunities regardless the site conditions, which was not the case of $\mathrm{T}$ system. By taking into consideration the results found for the shoot height, root collar diameter and root volume, it seems that the answer to the first question of this study is evident, emphasizing that the $\mathrm{M}$ seedbed tillage system provided better conditions for seedlings' growth and development.

\subsection{Condition of the Soils}

\subsubsection{Soil Condition in the Control Treatments}

Tables A1 and A2 are showing the laboratory results on the soil particle size distribution and chemical analysis. Particle size analysis (Table 1) has revealed important differences in distribution, particularly in the soil of FN3 as compared to the soils from FN1 and FN2. The main difference of the soil from FN3 was that it had a lower clay content at the expense of sand and silt. Also, compared to the soils from FN1 and FN2, there was a significantly higher share of coarse sand in FN3, standing for the main distinctive characteristic of the particle size distribution.

The main results of the chemical analysis (Table A2) have indicated the presence of an acid soil in FN3 (pH = 5.62) and of basic soils in FN1 (7.93) and FN2 (7.60), which have shown a relative invariance of $\mathrm{pH}$ values in relation to the sampling depth. Humus content was found to be in an average range in all the sampled layers and soils showing, in general, more favorable conditions for seedling growth and development in FN1 and FN2 as compared to FN3. Table fields of FN1 and FN2 which do not show any data (Table A2) are due to the common protocols used for soil samples analysis, which presuppose the determination of different chemical parameters as a function of the $\mathrm{pH}$ value. The threshold at which this decision is made stands for $\mathrm{pH}$ values less than 5.8.

\subsubsection{Changes in Soils' Physical Properties as an Effect of the Seedbed Tillage System}

Since the data characterizing the physical properties, as sampled at different depths, was checked to come from a normal distribution (results not shown herein), the changes in soils' physical characteristics were tested by paired parametric tests. Descriptive statistics and the results of statistical comparison tests have revealed contrasting differences as an effect of the soil type and of the implemented seedbed tillage system (Table A3). Com- 
pared to the control treatment, in FN1, for instance, there were no statistically significant differences in terms of bulk density as potentially induced by the seedbed tillage system. In FN2 and FN3, on the other hand, the implementation of the T system has led to significant differences in terms of bulk density which were characterized by lower figures as compared to the control treatment. Nevertheless, the comparison at the soil layer level having as a factor the forest nursery, has shown only few statistically significant differences. Similar changes were found for physical characteristics such as the soil porosity, water stock and compactness degree, standing for statistically significant differences as compared to the control treatments in FN2 and FN3. In the case of M treatment, there were few physical properties that were found to be different in terms of statistical significance when compared to the control treatment, namely those features which were related to the water content-soil moisture and water stock. Compared to the control and T treatment, the minimal (M) seedbed tillage system has generally provided more altered physical properties such as a higher bulk density, a lower moisture content, an intermediary porosity, and a higher soil compactness degree (Table A3).

\subsection{Dependence of Seedling Growth Parameters on the Soil Physical Properties \\ 3.3.1. Effect of Soil Physical Properties on Seedling Growth}

Table 6 shows the results and their significance following the implementation of correlation and linear regression analysis (a total number of 48 models were analyzed) in a pairwise comparison approach.

It is worth mentioning that the physical properties of the soils used in the analysis stand for the average values estimated based on the final state of the soils, following the implementation of the soil tillage systems, reflecting, therefore, the average condition of the soils before sowing or transplanting (Norway spruce). Also, the values used for the variables characterizing the growth (Table 6) stand for the average values computed based on the samples collected at the middle (root collar diameter, shoot height) and at the end (root volume) of the growing season.

Pairwise linear regression analysis did not reveal any significant dependence between the soils' physical properties and the root collar diameter $(\alpha=0.05, p<0.05)$, although the correlation analysis has outputted some interesting results. For instance, root collar diameter was positively, though moderately correlated with the soil's bulk density measured as the average value up to $10 \mathrm{~cm}$ in depth; therefore, it was negatively correlated to the soil porosity for the same soil depths. Soil compactness degree was also positively correlated with the root's collar diameter, though the intensity of correlation was low. Bulk density and soil's compactness degree were positively correlated with the root's collar diameter while porosity, moisture content and water stock were negatively correlated with this growth parameter.

The same correlation trends were preserved between the soils' physical properties and the shoot size with the main difference that the results have indicated lower associative relations between them (Table 6).

In what regards the root volume, the results were somehow different. First of all, the bulk density was found to be positively and moderately correlated with the root volume for soil depths of 10 to $30 \mathrm{~cm}$, and to a less extent for the first $10 \mathrm{~cm}$ in depth, a fact that is also reflected by the negative moderate correlation found for the soil porosity and for the same depth $(10$ to $30 \mathrm{~cm}$ ). Root volume was also found to be positively, though moderately, correlated with the soil compactness degree at depths of 10 to $30 \mathrm{~cm}$. On the other hand, moisture content and water stock in the first $10 \mathrm{~cm}$ were found to be highly to very highly negatively correlated and related to the root volume. As a fact, moisture content and water stock in these first $10 \mathrm{~cm}$ acted as significant predictors of the root volume (Table 6), explaining 75 to $91 \%$ of its variation by the determination coefficients given in Table 6 . Moisture content at depths of 10 to 20 and 20 to $30 \mathrm{~cm}$ has failed closely to become a significant predictor of the root volume variable. 
Table 6. Statistics of Correlation and Dependence of Seedling Growth Parameters on the Soil Physical Properties.

\begin{tabular}{|c|c|c|c|}
\hline \multirow{2}{*}{ Physical Property and Depth (cm) } & \multicolumn{3}{|c|}{ Coefficients of Correlation and Determination } \\
\hline & Root Collar Diameter (mm) & Shoot Height (cm) & Root Volume $\left(\mathrm{cm}^{3}\right)$ \\
\hline \multicolumn{4}{|l|}{ Bulk density $\left(\mathrm{g} \times \mathrm{cm}^{-3}\right)$} \\
\hline $0 \ldots 5$ & $0.503(0.252)$ & $0.428(0.183)$ & $0.417(0.174)$ \\
\hline $5 \ldots 10$ & $0.520(0.271)$ & $0.474(0.225)$ & $0.488(0.239)$ \\
\hline $10 \ldots 20$ & $0.490(0.240)$ & $0.409(0.167)$ & $0.673(0.452)$ \\
\hline $20 \ldots 30$ & $0.495(0.245)$ & $0.411(0.169)$ & $0.673(0.453)$ \\
\hline \multicolumn{4}{|l|}{ Moisture content (\%) } \\
\hline $0 \ldots 5$ & $-0.454(0.206)$ & $-0.433(0.187)$ & $-0.911(0.829) *$ \\
\hline $5 \ldots 10$ & $-0.435(0.189)$ & $-0.404(0.163)$ & $-0.929(0.863)^{* *}$ \\
\hline $10 \ldots 20$ & $-0.288(0.083)$ & $-0.165(0.027)$ & $-0.800(0.639)$ \\
\hline $20 \ldots 30$ & $-0.331(0.109)$ & $-0.173(0.030)$ & $-0.744(0.553)$ \\
\hline \multicolumn{4}{|l|}{ Porosity $(\%)$} \\
\hline $0 \ldots 5$ & $-0.503(0.253)$ & $-0.428(0.183)$ & $-0.417(0.174)$ \\
\hline $5 \ldots 10$ & $-0.520(0.271)$ & $-0.474(0.225)$ & $-0.488(0.239)$ \\
\hline $10 \ldots 20$ & $-0.490(0.240)$ & $-0.409(0.167)$ & $-0.673(0.453)$ \\
\hline $20 \ldots 30$ & $-0.495(0.245)$ & $-0.411(0.169)$ & $-0.673(0.453)$ \\
\hline \multicolumn{4}{|l|}{ Water stock $\left(\mathrm{m}^{3} \times \mathrm{ha}^{-1}\right)$} \\
\hline $0 \ldots 5$ & $-0.282(0.080)$ & $-0.320(0.103)$ & $-0.952(0.906) * *$ \\
\hline $5 \ldots 10$ & $-0.112(0.012)$ & $-0.136(0.019)$ & $-0.865(0.749) *$ \\
\hline $10 \ldots 20$ & $0.198(0.039)$ & $0.237(0.056)$ & $-0.280(0.078)$ \\
\hline $20 \ldots 30$ & $0.218(0.047)$ & $0.281(0.079)$ & $-0.160(0.026)$ \\
\hline \multicolumn{4}{|l|}{ Compactness degree (\%) } \\
\hline $0 \ldots 5$ & $0.461(0.213)$ & $0.416(0.173)$ & $0.394(0.155)$ \\
\hline $5 \ldots 10$ & $0.482(0.232)$ & $0.457(0.209)$ & $0.451(0.203)$ \\
\hline $10 \ldots 20$ & $0.455(0.207)$ & $0.393(0.154)$ & $0.626(0.392)$ \\
\hline $20 \ldots 30$ & $0.487(0.237)$ & $0.404(0.163)$ & $0.639(0.409)$ \\
\hline
\end{tabular}

Notes: Values given in the brackets stand for the coefficients of determination estimated by the pairwise linear regression analysis while the regular values stand fo the coefficients of correlation; Diagnoses indicated by ${ }^{* *}$ stand for $p$ values in the range of 0.01 to 0.001 , while diagnoses indicated by * stand for $p$ values in the range of 0.05 to 0.01 . Note: intensity of correlation was evaluated based on the rules of thumb described by the statistical textbooks as follows: correlation coefficient $(r)$ of \pm 0.90 to \pm 1.00 was interpreted as a very high positive (negative) correlation, $r$ of \pm 0.70 to \pm 0.90 was interpreted as a high correlation, $r$ of \pm 0.50 to \pm 0.70 was interpreted as a moderate correlation, $r$ of \pm 0.30 to \pm 0.50 was interpreted as a low correlation, and $r$ of \pm 0.00 to \pm 0.30 was interpreted as no (negligible) correlation.

To conclude on the effect of soils' physical properties in relation to the second objective of this study, it seems that their association with seedling growth variables was specific to the type of response variable, showing stronger associative effects with the root volume, where the latter was found to significantly depend only on the properties related to the soil water content in the first $10 \mathrm{~cm}$.

3.3.2. Similarity of Growth in Root Collar Diameter, Height and Root Volume as a Response to Seedbed Tillage System and Soil Properties

For the purpose of showing the similarity between nurseries, species and treatments based on outcome variables such as the root collar diameter and shoot height, a maximal clustering solution was kept for analysis to indicate the distances and the way that clusters form in respect to the physical properties of the soils. Figure 5 is showing the results when using the root collar diameter as a target variable, an approach which has been used because there were no important differences in clustering depending on the root collar diameter and shoot height. As shown, pedunculate oak and common ash formed a first cluster at the lowest Euclidian distance in the case of traditional system (T), which was specific to FN1. Next in line, and located at the same Euclidian distance was the cluster formed by the same species in the case of $\mathrm{M}$ treatment applied in FN1. Excepting the Norway spruce following the implementation of the $\mathrm{M}$ system, all the clusters tended to form themselves based on rather the implemented seedbed tillage system instead of forestry nursery, a fact that indicates a similarity between responses to the seedbed tillage systems rather than to soil types and climate specific to forest nurseries. This can be also 
seen in Figure 6a, by the way that silhouette values were computed and reported, indicating a strong cohesion of all clusters as of grouped per seedbed tillage system (values ranging, in general, from 0.3 to 0.8 ). The only exception found here was the same, characterizing the Norway spruce as of implementing the $\mathrm{M}$ system, which explains the dendrogram given in Figure 5. This result is not surprising if one checks the data reported in Table 3, which indicates the lowest changes of the root collar diameter and shoot height of this species as an effect of seedbed tillage system.

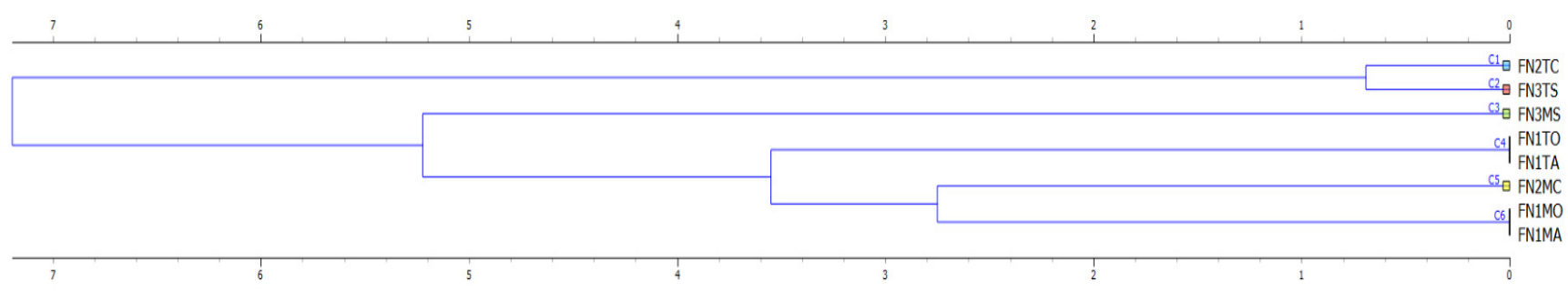

Figure 5. Dendrogram showing the hierarchical clustering of the forest nurseries, tillage systems and species based on the root collar diameter (target variable), as a function of physical properties of the soils before sowing (transplanting). Legend: abbreviations of the right side of the figure are explained in Table 3, horizontal axis stands for the Euclidian distance.

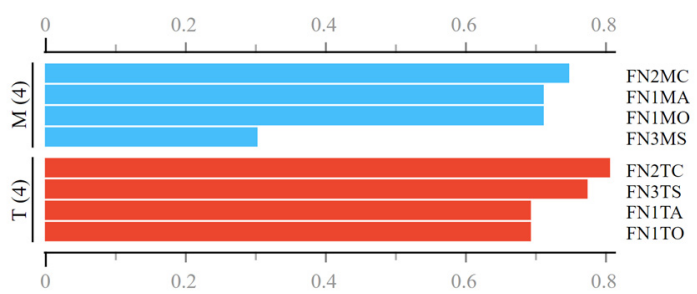

(a)

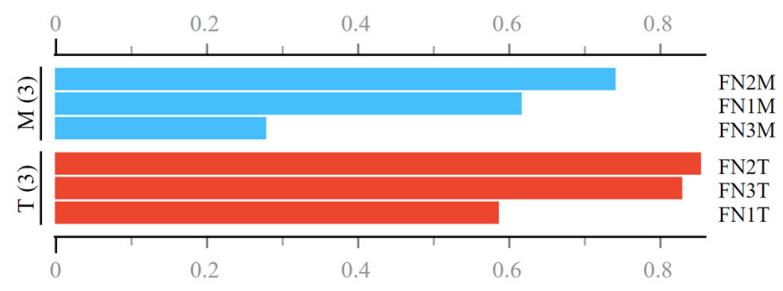

(b)

Figure 6. Silhouette plots showing the consistency of the clusters. Legend: (a) silhouette plots of the clusters shown in Figure 5, (b) silhouette plots of the clusters shown in Figure 7.

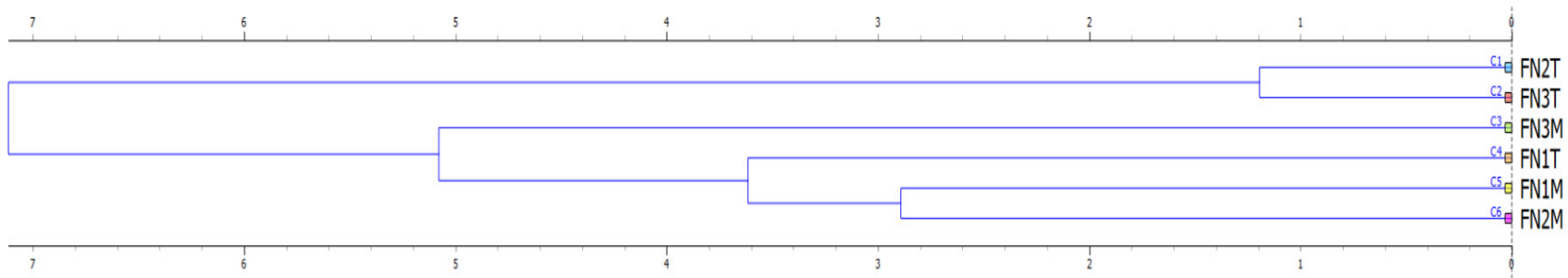

Figure 7. Dendrogram showing the hierarchical clustering of the forest nurseries and tillage systems based on the root volume (target variable), as a function of the physical properties of the soils before sowing (transplanting). Legend: abbreviations of the right side of the figure are explained in Table 3 and exclude the species, horizontal axis stands for the Euclidian distance.

Similar results (Figures $6 \mathrm{~b}$ and 7 ) were found when using the root volume variable as a target for hierarchical clustering, with the difference that this approach has excluded the effect of species since the data was available only for the pedunculate oak. Excepting the case of FN3M, all the silhouette values were found to range between ca. 0.6 and 0.9 indicating, therefore a good outcome of clustering in terms of cohesion. The placement of FN1T among the group of M treatments could be the effect of data similarity (low differences) in terms of soil physical properties for the FN1 (Table A3). To conclude, the main variable contributing to the similarity of outcomes in terms of seedling growth was the type of seedbed tillage system. As such, hierarchical clustering has shown that the 
outcomes are similar in terms of growth variables when treated under the same type of seedbed tillage system. However, there were some dissimilarities which were brought, for instance, by the low differences in growth (Norway spruce).

\section{Discussion}

Outplanting success depends on the interaction between the quality of the planted stock and its environment $[3,38]$, and it has been argued that the seedlings' phenotype, characterized by morphological, anatomical and physiological attributes, could be more important in predicting survival and growth, even though comparative experiments should account for all the relevant factors [39] to describe such interactions. Since accounting for all interactions is difficult, forest nurseries are commonly guiding their practices based on the local experience, national standards and outcomes provided by comparative studies relating the survival and growth to the morphological characteristics of the seedlings at their lifting.

From this point of view, and based on the findings of several studies [40-47], including part of those referenced in the introduction section, one can conclude that morphological features such as a higher root collar diameter, shoot height and root volume, are desirable features to improve outplanting success. Many of such morphological features can be achieved by a variety of nursery practices such as manipulating the used substrates [48], seedling growing regime [30], and seedbed growing density [49], and may help reducing seedling production costs and time [48,49].

Acknowledging that the effects of seedbed cultivation techniques on morphological development of plants could have been tested for various industries, unfortunately, no studies were found to compare such changes for seedlings of forest species. In addition, practices used in forest nurseries may differ largely [30], with many of them adopting and using a given seedbed preparation system, making the comparisons even more difficult. Rototilling is assumed to create aggregates that are too small as compared to the optimum growth range ( 0.5 to $2 \mathrm{~mm}$ ), though it is seen to be the easiest way to provide conditions for a uniform germination, being commonly used in some countries [27]. When implemented uncarefully, it also could lead to producing very small soil particles [50], which may have unfavorable consequences on plant development [3]. However, many plants were found to respond differently to the soil particle size in the presence, or as an effect, of other characteristics such as the clay content, climate, artificial (intended) compaction, drainage and aeration [51]. As indicated by this study, all of the morphological features measured for seedlings were positively and significantly changed as an effect of implementing the minimal (M) system. The assumption according to which these changes were the effect of the seedbed tillage system holds true, since a relative control was maintained over other important factors such as the sowing (rowing) system, fertilizer and irrigation administration, which were, more or less the same, irrespective of the forest nursery and species under study. Particle size distribution was not measured in this study following the implementation of the seedbed tillage systems, but the soil tilth was found to be finer following the M system (particularly in FN1 and FN2). Having in mind the potential differences in growth between various species, as well as the fact that vigor of the shoots is a reflection of the health of the roots [27], a finer soil tilth following the $\mathrm{M}$ system had contrasting effects. Acknowledging the potential stress induced by transplantation, for Norway spruce seedlings, a species which is known to invest in lateral roots [36], the growth gains were less, even though they were statistically significant. For pedunculate oak seedlings, on the other hand, the condition of the soil following the implementation of the $\mathrm{M}$ system was more favorable for the development of the root system.

A typical distinctive feature of the minimal (M) system was that it contributed to the bulk density increment in most of the sampled soil layers, although the difference was not statistically significant compared to the control plots. However, according to the particle size analysis which is commonly used as a categorization criterion of soils [35], the soils from FN1 and FN2 were clay loams while the soil form FN3 was a sandy loam. It has been 
indicated that optimal bulk densities for seedling growth on clay loams and sandy soils are of 1.0 to 1.1 , and $1.45 \mathrm{~g} \times \mathrm{cm}^{-3}$, respectively, with an ideal figure of $1.3 \mathrm{~g} \times \mathrm{cm}^{-3}$ in the case of sandy loams [27]. Bulk density figures found by this study were much higher than those reported in literature as optimal, though they were not different, in general, between the control (C), and minimal (M) system. As such, it is likely for differences found in terms of morphological attributes, as of using the $\mathrm{M}$ system, not to be directly related to the changes in soils' bulk density, as opposite to some controlled experiments that have shown that bulk densities of ca. $1.6 \mathrm{~g} \times \mathrm{cm}^{-3}$ limited the ability of holm oak to develop fine roots [52]. As a fact, the factors which were inversely and significantly (co)related to the gains in morphological attributes were only the moisture content and water stock in the first $10 \mathrm{~cm}$, as specific to the implementation of the $\mathrm{M}$ system. Similar mechanisms were found to affect seedling development following outplanting [21]. However, these parameters are commonly altered by the following operations such as the manual cultivation to remove the competing vegetation, which was implemented in all the forest nurseries, and irrigation schedules, therefore their effects may not be relevant for the final outcome in terms of seedling growth, while by the implementation of cultivation operations the bulk density, porosity and compactness degree could have been changed in the first $(10 \mathrm{~cm})$ layer of the soil. Having these in mind, as well as the fact that changes in soil compactness affect the development of roots indirectly by the changes in the structural architecture, strength, total porosity, proportion of large pores, water content and hydraulic conductivity, air content and diffusion rate of the gases [53], which could result in plant-specific establishment and growth dynamics, typically characterized by species limitations to some factors, it seems that the implementation of the $\mathrm{M}$ system has produced improved conditions for seedling growth, by altering several physical properties of the soils.

On the other hand, it is worth to mention that one of the distinctive features of the T seedbed preparation system was that it produced the highest (43.38 to $49.48 \%$, significantly different in FN2 and FN3 compared to control) soil porosity, which was close to that indicated as being optimal [27]. Nevertheless, T performed poorer in terms of seedling growth outcomes as compared to the $\mathrm{M}$ system. This effect could be attributed to the soil tilth condition and to the type of contact made by the seeds with the soil's particles, which probably was weaker in the case of the T system, therefore it induced a development latency as compared to the $\mathrm{M}$ system. In this respect, soil porosity is known to be a dynamic feature influenced by the natural conditions and artificial interventions and some work has found that an increased pore space may negatively affect the establishment of plants [54].

Expectedly, the morphological features taken into study were ranked similarly by the soils' physical properties, indicating separate clusters which were consistently formed around the two seedbed tillage systems. However, in the case of the root collar diameter (and shoot height), there was an outlying cluster characterizing the M system applied in FN3 to the Norway spruce plot, which merged at a higher distance with the rest of M treatments. Accordingly, FN3 under the M system has clustered in a similar way when using the root volume (pedunculate oak) as a target variable. These were the cases in which the M system was either less effective (but statistically different) in terms of root collar diameter and shoot height (Norway spruce) or the most effective in terms of root volume (pedunculate oak), indicating therefore, different though positive, degrees of effectiveness in relation to these two seedling species.

Targeted physical properties of the seedbeds are assumed to be those enabling optimal environments for root growth and functioning [27], and minimal interventions aiming at seedbed preparation as a management practice are desirable from many points of view, including the avoidance of excessive soil compaction, economizing resources, and improving the growth outputs. While the $\mathrm{M}$ seedbed tillage system performed better, it is worth to mention other of its features even though they are rather informally given herein. By the used equipment and outcome of operations, scarifying followed by rototilling is sufficient to produce improved properties of the soils in the seedbeds. Although no measurements were done to check the operational performance in terms of time and fuel 
consumption, economic efficiency and productivity, rules of thumb indicate that such performance metrics are typically improved when limiting the number of operations or passes [55]. However, the main differences in terms of productivity may rest in the width of operated area per turn, with some work indicating that rototilling may be three times less performant in this respect as compared to disk harrowing [31]. Assuming these findings, as well as the limited space for turning the equipment at the nursery headlands, it is reasonably to think that the implementation of an additional cultivation as of using the $\mathrm{T}$ system, would match, more or less, the time and fuel consumption as of using the M system. Nevertheless, the $\mathrm{M}$ system requires two passes, and provided much better conditions in terms of seedling growth. Altogether, these could contribute to either a better responsivity of the forest nurseries, by shortening the production time, or to the provision of better developed morphological features of the seedlings, assuming that the production time will be kept the same. For instance, the minimum root collar diameters required for outplanting pedunculate oak, common ash, wild cherry and Norway spruce in Romania are of 5-7, 8-10, 4-6 and 7-8 $\mathrm{mm}$, respectively [56]. The use of the $\mathrm{M}$ system has led to reaching this minimum value by the mid-growing season in the case of wild cherry, and figures close to these targets were specific also to most of the species taken into study (e.g., common ash, pedunculate oak).

\section{Conclusions}

The main conclusion of this study is that the minimal seedbed tillage system (scarifying followed by rototilling) has significantly outperformed the traditional one (plowing, disk harrowing and cultivating) in terms of seedling growth. The benefits that could be brought by updating the practice to using the minimal system are those related to the responsivity, seedling quantity and quality increment, as well as to the space saving in the forest nurseries; as such, the forest nurseries would be enabled by the use of this system in producing more high-quality seedlings, in less time, by using the same production space. This holds true at least for the four tested species which have shown an improved growth as an effect of using the minimal seedbed tillage system; nevertheless, more scaled studies would be required to test the systems' effectiveness for other tree species and under more varied vegetation and soil conditions. In addition, the resources used in forest nurseries for seedling production, including the available production space, stand apart as an important topic, therefore the question on whether the minimal seedbed tillage system would result in a better operational performance, as compared to the traditional one, needs to be pursued by studies in the future.

Author Contributions: Conceptualization, N.B. and S.A.B.; methodology, N.B. and S.A.B.; validation, N.B. and S.A.B.; formal analysis, S.A.B.; investigation, N.B.; resources, N.B.; data curation, N.B. and S.A.B.; writing —original draft preparation, N.B. and S.A.B.; writing — review and editing, N.B. and S.A.B.; visualization, S.A.B. All authors have read and agreed to the published version of the manuscript.

Funding: This research received no external funding.

Data Availability Statement: Data supporting this study may be provided on request to the first author of the study.

Acknowledgments: The authors would like to thank to the management of the three forest nurseries for supporting this study. Also, the authors would like to thank to the staff of the soil testing laboratory of the Agricultural Directorate of Arad (Romania). The authors acknowledge the logistical support provided to support this study by the Department of Forest Engineering, Forest Management Planning and Terrestrial Measurements, Faculty of Silviculture and Forest Engineering, Transilvania University of Braşov.

Conflicts of Interest: The authors declare no conflict of interest. 


\section{Appendix A}

Table A1. Results of the analysis on soil particle size.

\begin{tabular}{|c|c|c|c|c|c|c|}
\hline \multirow{2}{*}{$\begin{array}{l}\text { Forest Nursery } \\
\text { (Soil) }\end{array}$} & \multirow{2}{*}{$\begin{array}{l}\text { Sampling } \\
\text { Depth }(\mathrm{cm})\end{array}$} & \multicolumn{2}{|c|}{ Sand $(\%)$} & \multicolumn{2}{|c|}{ Silt (\%) } & \multirow{2}{*}{$\begin{array}{c}\text { Clay (\%) } \\
<0.0002 \mathrm{~mm}\end{array}$} \\
\hline & & $>0.2 \mathrm{~mm}$ & $0.2-0.02 \mathrm{~mm}$ & $0.02-0.01 \mathrm{~mm}$ & $0.01-0.0002 \mathrm{~mm}$ & \\
\hline \multirow{5}{*}{$\begin{array}{c}\text { FN1 } \\
\text { (Fluvisol) }\end{array}$} & $0-10$ & 1.7 & 39.0 & 14.5 & 24.2 & 20.6 \\
\hline & $10-20$ & 1.8 & 37.5 & 14.1 & 23.0 & 23.8 \\
\hline & 20-30 & 2.4 & 39.5 & 14.5 & 18.5 & 25.2 \\
\hline & Average & 2.0 & 38.7 & 14.3 & 21.9 & 23.2 \\
\hline & $0-10$ & 0.7 & 36.0 & 16.9 & 16.9 & 29.5 \\
\hline FN2 & $10-20$ & 2.3 & 45.4 & 12.5 & 12.5 & 27.3 \\
\hline \multirow[t]{3}{*}{ (Luvisol) } & 20-30 & 1.8 & 39.3 & 16.5 & 13.8 & 28.6 \\
\hline & Average & 1.6 & 40.2 & 15.3 & 14.4 & 28.5 \\
\hline & $0-10$ & 23.9 & 31.1 & 8.0 & 22.0 & 15.0 \\
\hline FN3 & $10-20$ & 28.2 & 30.8 & 9.0 & 16.0 & 16.0 \\
\hline \multirow{2}{*}{ (Cambisol) } & $20-30$ & 25.2 & 31.8 & 9.0 & 16.5 & 17.5 \\
\hline & Average & 25.8 & 31.2 & 8.7 & 18.2 & 16.2 \\
\hline
\end{tabular}

Table A2. Results of the analysis on chemical properties of the soils.

\begin{tabular}{|c|c|c|c|c|c|c|c|c|c|c|c|c|}
\hline $\begin{array}{c}\text { Forest } \\
\text { Nurs- } \\
\text { ery }\end{array}$ & $\begin{array}{l}\text { Sampling } \\
\text { Depth } \\
(\mathrm{cm})\end{array}$ & $\mathrm{pH}$ & IN & $\begin{array}{c}\mathrm{Ah} \\
\text { (me/100 g) }\end{array}$ & $\begin{array}{c}\text { SB } \\
(\mathrm{me} / 100 \mathrm{~g})\end{array}$ & $\begin{array}{c}\text { AI } \\
(\mathrm{me} / 100 \mathrm{~g})\end{array}$ & $\begin{array}{c}\text { Carbonates } \\
(\%)\end{array}$ & $\begin{array}{l}\text { Humus } \\
(\%)\end{array}$ & $\begin{array}{l}N \\
(\%)\end{array}$ & $\begin{array}{c}\mathrm{N}-\mathrm{NO}_{3} \\
\text { (ppm) }\end{array}$ & $\begin{array}{l}\mathrm{P}(\mathrm{AL}) \\
(\mathrm{ppm})\end{array}$ & $\begin{array}{l}\mathrm{K}(\mathrm{AL}) \\
(\mathrm{ppm})\end{array}$ \\
\hline & $0-10$ & 7.85 & - & - & - & - & 1.30 & 2.95 & 0.143 & 1.4 & 14.6 & 150 \\
\hline FN1 & 10-20 & 8.00 & - & - & - & - & 2.70 & 2.40 & 0.118 & 5.3 & 14.5 & 200 \\
\hline \multirow{3}{*}{ (Fluvisol) } & $20-30$ & 7.95 & - & - & - & - & 4.30 & 1.70 & 0.079 & 5.9 & 13.5 & 127 \\
\hline & Average & 7.93 & - & - & - & - & 2.77 & 2.35 & 0.113 & 4.20 & 14.20 & 159 \\
\hline & 0-10 & 7.50 & - & - & - & - & 2.15 & 3.20 & 0.157 & 9.6 & 20.6 & 188 \\
\hline FN2 & $10-20$ & 7.60 & - & - & - & - & 1.75 & 3.50 & 0.172 & 7.6 & 19.7 & 192 \\
\hline \multirow[t]{3}{*}{ (Luvisol) } & $20-30$ & 7.70 & - & - & - & - & 1.25 & 2.50 & 0.120 & 4.5 & 16,6 & 175 \\
\hline & Average & 7.60 & - & - & - & - & 1.72 & 3.07 & 0.150 & 7.23 & 18.97 & 185 \\
\hline & 0-10 & 5.75 & 2.18 & 4.90 & 17.20 & 0.05 & - & 2.80 & 0.137 & 1.8 & 9.0 & 65 \\
\hline \multirow{3}{*}{$\begin{array}{l}\text { FN3 } \\
\text { (Cambisol) }\end{array}$} & 10-20 & 5.50 & 1.14 & 6.60 & 16.40 & 0.50 & - & 1.60 & 0.077 & 4.4 & 9.0 & 96 \\
\hline & l) 20-30 & 5.60 & 0.69 & 6.05 & 16.00 & 0.45 & - & 0.95 & 0.045 & 3.9 & 9.0 & 90 \\
\hline & Average & 5.62 & 1.34 & 5.85 & 16.53 & 0.33 & - & 1.78 & 0.086 & 3.37 & 9.00 & 84 \\
\hline
\end{tabular}

Note: $\mathrm{pH}$-soil's $\mathrm{pH}, \mathrm{IN}$-nitrogen index, Ah-hydrolytic acidity, SB-content in bases, AI—content in Aluminium, N—Nitrogen, $\mathrm{N}-\mathrm{NO}_{3}$-nitric Nitrogen, $\mathrm{P}(\mathrm{Al})$ - mobile Phosphor, $\mathrm{K}(\mathrm{Al})$-Potassium. 
Table A3. Descriptive statistics and results of comparison tests on soils' physical properties.

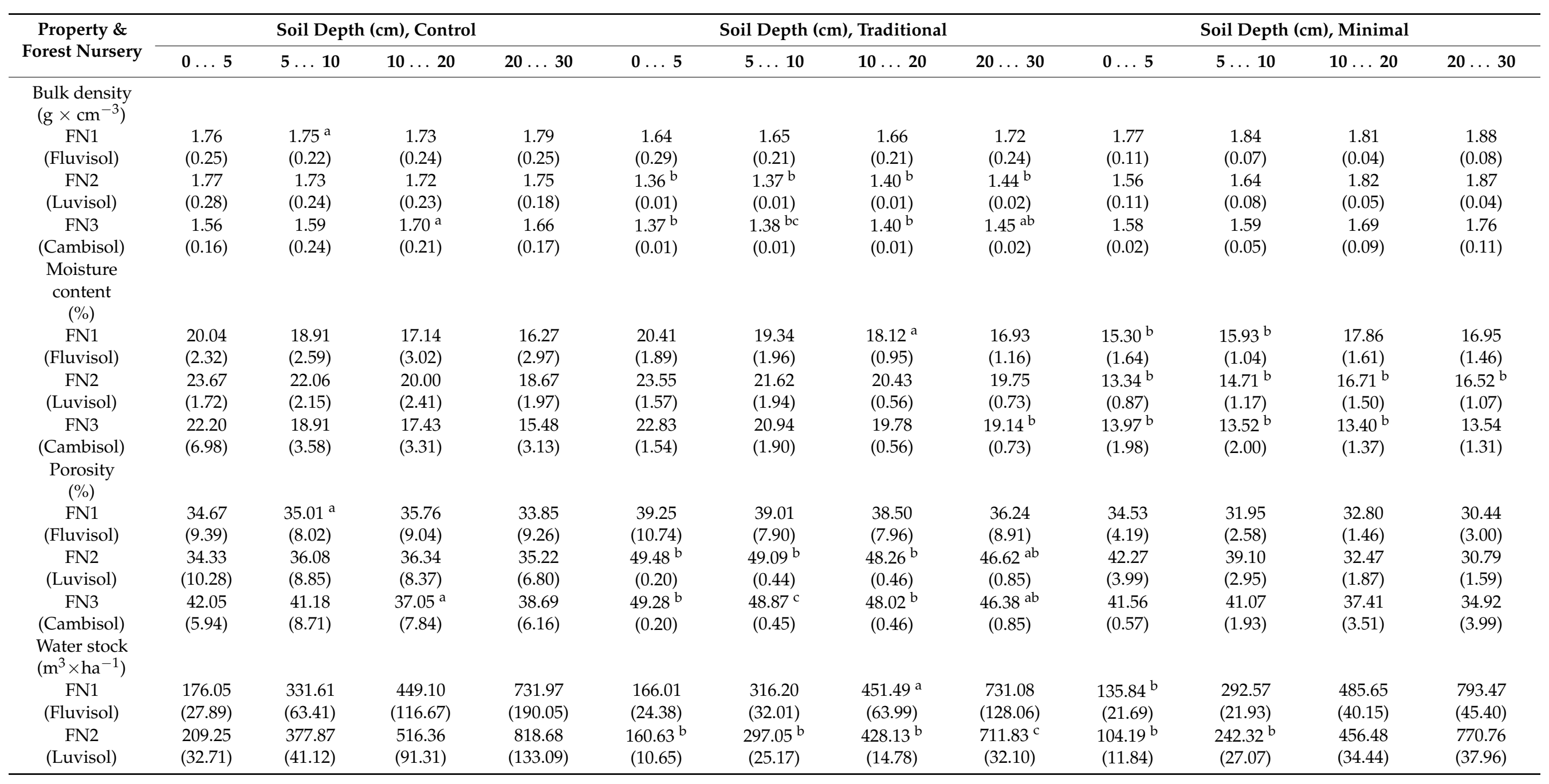


Table A3. Cont.

\begin{tabular}{|c|c|c|c|c|c|c|c|c|c|c|c|c|}
\hline \multirow{2}{*}{$\begin{array}{c}\text { Property \& } \\
\text { Forest Nursery }\end{array}$} & \multicolumn{4}{|c|}{ Soil Depth $(\mathrm{cm})$, Control } & \multicolumn{4}{|c|}{ Soil Depth (cm), Traditional } & \multicolumn{4}{|c|}{ Soil Depth (cm), Minimal } \\
\hline & $0 \ldots 5$ & $5 \ldots 10$ & $10 \ldots 20$ & $20 \ldots 30$ & $0 \ldots 5$ & $5 \ldots 10$ & $10 \ldots 20$ & $20 \ldots 30$ & $0 \ldots 5$ & $5 \ldots 10$ & $10 \ldots 20$ & $20 \ldots 30$ \\
\hline $\begin{array}{c}\text { FN3 } \\
\text { (Cambisol) }\end{array}$ & $\begin{array}{l}174.96 \\
(58.96)\end{array}$ & $\begin{array}{l}301.58 \\
(73.19)\end{array}$ & $\begin{array}{c}448.95 \\
(118.51)\end{array}$ & $\begin{array}{c}649.23 \\
(178.62)\end{array}$ & $\begin{array}{l}156.35 \\
(10.47)\end{array}$ & $\begin{array}{l}288.94 \\
(24.76)\end{array}$ & $\begin{array}{l}416.42 \\
(14.65)\end{array}$ & $\begin{array}{l}692.84 \\
(31.86)\end{array}$ & $\begin{array}{c}110.11^{b} \\
(14.74)\end{array}$ & $\begin{array}{c}215.48^{b} \\
(35.72)\end{array}$ & $\begin{array}{l}340.06^{\mathrm{c}} \\
(42.14)\end{array}$ & $\begin{array}{l}595.12 \\
(70.20)\end{array}$ \\
\hline $\begin{array}{c}\text { Compactness } \\
(\%)\end{array}$ & & & & & & & & & & & & \\
\hline $\begin{array}{c}\text { FN1 } \\
\text { (Fluvisol) }\end{array}$ & $\begin{array}{c}28.36 \\
(19.40)\end{array}$ & $\begin{array}{l}28.27^{\mathrm{a}} \\
(16.44)\end{array}$ & $\begin{array}{c}27.19 \\
(18.41)\end{array}$ & $\begin{array}{c}31.05 \\
(18.86)\end{array}$ & $\begin{array}{c}18.89 \\
(22.20)\end{array}$ & $\begin{array}{c}20.09 \\
(16.19)\end{array}$ & $\begin{array}{c}21.59 \\
(16.21)\end{array}$ & $\begin{array}{c}26.17 \\
(18.15)\end{array}$ & $\begin{array}{l}28.64 \\
(8.67)\end{array}$ & $\begin{array}{l}34.54 \\
(5.29)\end{array}$ & $\begin{array}{l}33.21 \\
(2.98)\end{array}$ & $\begin{array}{l}37.99 \\
(6.12)\end{array}$ \\
\hline $\begin{array}{c}\text { FN2 } \\
\text { (Luvisol) }\end{array}$ & $\begin{array}{l}28.35 \\
(21.46)\end{array}$ & $\begin{array}{l}25.04 \\
(18.39)\end{array}$ & $\begin{array}{l}24.86 \\
(17.32)\end{array}$ & $\begin{array}{c}27.35 \\
(14.04)\end{array}$ & $\begin{array}{l}0.65^{\mathrm{b}} \\
(0.40)\end{array}$ & $\begin{array}{l}1.21^{\mathrm{b}} \\
(0.88)\end{array}$ & $\begin{array}{l}2.83^{b} \\
(0.93)\end{array}$ & $\begin{array}{c}3.82 \mathrm{ab} \\
(1.75)\end{array}$ & $\begin{array}{l}15.13 \\
(8.01)\end{array}$ & $\begin{array}{l}21.33 \\
(5.94)\end{array}$ & $\begin{array}{l}34.61 \\
(3.78)\end{array}$ & $\begin{array}{l}36.47 \\
(3.28)\end{array}$ \\
\hline $\begin{array}{c}\text { FN3 } \\
\text { (Cambisol) }\end{array}$ & $\begin{array}{c}11.37 \\
(12.52)\end{array}$ & $\begin{array}{l}13.39 \\
(18.32)\end{array}$ & $\begin{array}{l}22.17^{a} \\
(16.47)\end{array}$ & $\begin{array}{c}19.15 \\
(12.88)\end{array}$ & $\begin{array}{l}-3.86^{\mathrm{b}} \\
(0.42)\end{array}$ & $\begin{array}{l}-2.79^{\mathrm{c}} \\
(0.94)\end{array}$ & $\begin{array}{l}-0.87^{\mathrm{b}} \\
(0.97)\end{array}$ & $\begin{array}{c}3.09 \mathrm{ab} \\
(1.78)\end{array}$ & $\begin{array}{l}12.41 \\
(1.20)\end{array}$ & $\begin{array}{l}13.61 \\
(4.05)\end{array}$ & $\begin{array}{l}21.41 \\
(7.37)\end{array}$ & $\begin{array}{l}27.03 \\
(8.33)\end{array}$ \\
\hline
\end{tabular}

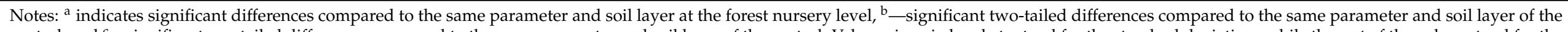

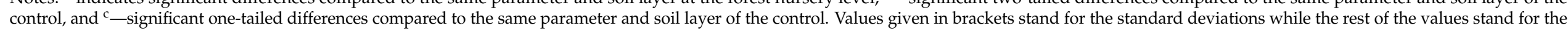
means. 


\section{References}

1. FAO. The State of the World's Forests. Forests, Biodiversity and People; FAO: Rome, Italy, 2020; p. 188, ISSN $2521-7542$.

2. Mexal, J.G.; Landis, T.D. Target seedling concepts: Height and diameter. In Proceedings of the Target Seedling Symposium: Combined Meeting of the Western Forest Nursery Associations, Roseburg, OR, USA, 13-17 August 1990; General Technical Report, RM-200. Rose, R., Campbell, S.J., Landis, T.D., Eds.; Department of Agriculture, Forest Service, Rocky Mountain Forest and Range Experiment Station: Fort Collins, CO, USA, 1990; pp. 17-35.

3. Abrudan, I.V. Impăduriri; Transilvania University Press: Brașov, Romania, 2006; ISBN 973-635-688-4.

4. Boja, N.; Boja, F.; Teusdea, A.; Vidrean, D.; Marcu, M.V.; Iordache, E.; Duţă, C.I.; Borz, S.A. Resource allocation, pit quality, and early survival of seedlings following two motor-manual pit-drilling options. Forests 2018, 9, 665. [CrossRef]

5. Ersson, B.T.; Laine, T.; Saksa, T. Mechanized tree planting in Sweden and Finland: Current state and key factors for future growth. Forests 2018, 9, 370. [CrossRef]

6. Gray, L.K.; Hamann, A. Strategies for reforestation under uncertain future climates: Guidelines for Alberta, Canada. PLoS ONE 2011, 6, e22977. [CrossRef] [PubMed]

7. Heiskanen, J.; Saksa, T.; Luoranen, J. Soil preparation method affects outplanting success of Norway spruce container seedlings on till soils susceptible to frost heave. Silva. Fenn 2013, 47, 893. [CrossRef]

8. Luoranen, J.; Saksa, T.; Lappi, J. Seedling, planting site and weather factors affecting the success of autumn plantings in Norway spruce and Scot pine seedlings. For. Ecol. Manag. 2018, 419, 79-90. [CrossRef]

9. McDonald, T.P.; Fulton, J.P.; Darr, M.J.; Gallagher, T.V. Evaluation of a system to spatially monitor hand planting of pine seedlings. Comput. Electron. Agric. 2008, 64, 173-182. [CrossRef]

10. Renou-Wilson, F.; Keane, M.; Farrel, E.P. Effect of planting stocktype and cultivation treatment on the establishment of Norway spruce on cutaway peatlands. New For. 2008, 36, 307-330. [CrossRef]

11. Hallsby, G.; Örlander, G. A comparison of mounding and inverting to establish Norway spruce on podzolic soils in Sweden. Forestry 2004, 77, 107-117. [CrossRef]

12. Buitrago, M.; Paquette, A.; Thiffault, N.; Bélanger, N.; Messier, C. Early performance of planted hybrid larch: Effects of mechanical site preparation and planting depth. New For. 2015, 46, 319-377. [CrossRef]

13. Harrington, T.B.; Howell, K.D. Planting cost, survival, and growth one to three years after establishing loblolly pine seedlings with straight, deformed or pruned roots. New For. 1998, 15, 193-204. [CrossRef]

14. Laine, T.; Saarinen, V.-M. Comparative study of the Risutec automatic plant container (APC) and Bracke planting devices. Silva Fenn. 2014, 48. [CrossRef]

15. Luoranen, J.; Rikala, R. Field performance of Scots pine (Pinus sylvestris L.) seedlings planted in disk trenched or mounded sites over an extended planting season. New For. 2013, 44, 147-162. [CrossRef]

16. Luoranen, J.; Viiri, H. Deep planting decreases risk of drought damage and increases growth of Norway spruce container seedlings. New For. 2016, 47, 701-714. [CrossRef]

17. Luoranen, J. Autumn versus spring planting: The initiation of root growth and subsequent field performance of Scots pine and Norway spruce seedlings. Silva Fenn. 2018, 52. [CrossRef]

18. Luoranen, J.; Rikala, R.; Smolander, H. Machine planting of Norway spruce by Bracke and Ecoplanter: An evaluation of soil preparation, planting method and seedling performance. Silva Fenn. 2011, 45, 341-357. [CrossRef]

19. Niuwenhuis, M.; Egan, D. An evaluation and comparison of mechanised and manual tree planting on afforestation and reforestation sites in Ireland. Int. J. For. Eng. 2002, 3, 11-23. [CrossRef]

20. Marchi, E.; Chung, W.; Visser, R.; Abbas, D.; Nordfjell, T.; Mederski, P.S.; McEwan, A.; Brink, M.; Laschi, A. Sustainable forest operations (SFO): A new paradigm in a changing world and climate. Sci. Total Environ. 2018, 634, 1385-1397. [CrossRef] [PubMed]

21. Heinimann, H.R. Forest operations engineering and management-The ways behind and ahead a scientific discipline. Croat. J. For. Eng 2007, 28, 107-121.

22. Grossnickle, S.C. Why seedlings survive: Influence of plant attributes. New For. 2012, 43, 711-738. [CrossRef]

23. Grossnickle, S.C.; MacDonald, J.E. Why seedlings grow: Influence of plant attributes. New For. 2018, 49, 1-34. [CrossRef]

24. Binkley, D.; Fisher, R.F. Ecology and Management of Forest Soils; John Wiley \& Sons, Ltd.: Hoboken, NJ, USA, 2013 ; p. 347. ISBN 9781118422342.

25. Bejarano, M.D.; Villar, R.; Murillo, A.M.; Quero, J.L. Effects of soil compaction and light on growth of Quercus pyrenaica Willd. (Fagaceae) seedlings. Soil Tillage Res. 2010, 110, 108-114. [CrossRef]

26. Alameda, D.; Villar, R. Moderate soil compaction: Implication on growth and architecture in seedlings of 17 woody plant species. Soil Tillage Res. 2009, 103, 325-331. [CrossRef]

27. Forest Nursery Manual: Production of Bareroot Seedlings; Duryea, M.L.; Landis, T.D. (Eds.) Oregon State University: Corvallis, OR, USA, 1984; p. 386.

28. Moskalik, T.; Borz, S.A.; Dvorák, J.; Ferencik, M.; Glushkov, S.; Muiste, P.; Lazdinš, A.; Styranivsky, O. Timber harvesting methods in Eastern European countries: A review. Croat. J. For. Eng. 2017, 38, 231-241.

29. National Forest Administration—RNP Romsilva: Forest Nurseries. Available online: http://www.rosilva.ro/articole/pepiniere_ silvice__p_130.htm (accessed on 9 April 2021). 
30. Del Campo, A.D.; Navarro, R.M.; Ceacero, C.J. Seedling quality and field performance of commercial stocklots of containerized holm oak (Quercus ilex) in Mediterranean Spain: An approach for establishing a quality standard. New For. 2010, $39,19-37$. [CrossRef]

31. Marogel-Popa, T.; Marcu, M.V.; Nuţă, I.S.; Borz, S.A. Evaluarea productivităţii şi a condiţiilor ergonomice posturale în operaţii mecanizate de întreţinere a solului realizate cu agregate pentru discuit şi frezat în culture de plop. Revista Pădurilor 2019, 134, 31-48.

32. Marcu, M. Meteorologie şi Climatologie Forestieră; Ceres Publishing House: Bucureşti, Romania, 1983; pp. $184-186$.

33. FAO. World Reference Base for Soil Resources 2014. International Soil Classification System for Naming Soils and Creating Legends for Soil Maps. Update 2015. World Soil Resources Report 106. 2015. Available online: http://www.fao.org/3/i3794en/I3794en.pdf (accessed on 9 April 2021).

34. Canarache, A.; Șerbănescu, I.; Teaci, D. , Savopol, L. Îndrumător Pentru Studiul Solului pe Teren şi în Laborator; Agro-Silvică Publishing House: Bucharest, Romania, 1990.

35. Osman, K.T. Forest Soils. Properties and Management; Springer: Cham, Switzerland, 2013; p. 217. ISBN 978-3-319-02541-4.

36. Şofletea, N.; Curtu, L. Dendrologie, 2nd ed.; “Pentru Viaţă” Publishing House: Brasov, Romania, 2008; p. 419. ISBN 978-973-85874-4-1.

37. Demsar, J.; Curk, T.; Erjavec, A.; Gorup, C.; Hocevar, T.; Milutinovic, M.; Mozina, M.; Polajnar, M.; Toplak, M.; Staric, A.; et al. Orange: Data Mining Toolbox in Python. J. Mach. Learn. Res. 2013, 14, 2349-2353.

38. Burdett, A.N. Quality control in the production of forest planting stock. For. Chron. 1983, 59, 132-138. [CrossRef]

39. Chavasse, C.G.R. Planting stock quality: A review of factors affecting performance. N. Z. J. For. Sci. 1980, $25,144-171$.

40. Dey, D.C.; Parker, W.C. Morphological indicators of stock quality and field performance of red oak (Quercus rubra L.) seedlings underplanted in a central Ontario shelterwood. New For. 1997, 14, 145-156. [CrossRef]

41. Grossnickle, S.C. Seedling size and reforestation success. How big is enough? Forest Research Information Paper. In The Thin green line. Proceedings of a Symposium on the State-of-Art in Reforestation, Thunder Bay, ON, Canada, 26-28 July 2005; Ontario Forest Research Institute: Sault Ste. Marie, ON, Canada, 2005; Volume 160, pp. 144-149.

42. Ivetić, V.; Devetaković, J.; Maksimović, Z. Initial height and diameter are equally related to survival and growth of hardwood seedlings in first year after field planting. Reforesta 2016, 2, 6-21. [CrossRef]

43. Ivetić, V.; Grossnickle, S.; Škorić, M. Forecasting the field performance of Austrian pine seedlings using morphological attributes. iForest 2016, 10, 99-107. [CrossRef]

44. South, D.B.; Rakestraw, J.L.; Lowerts, G.A. Early gains from planting large-diameter seedlings and intensive management are additive for loblolly pine. New For. 2001, 22, 97-110. [CrossRef]

45. Davis, A.S.; Jacobs, D.F. Quantifying root system quality of nursery seedlings and relationship to outplanting performance. New For. 2005, 30, 295-311. [CrossRef]

46. Grossnickle, S.C. Importance of root growth in overcoming planting stress. New For. 2005, 30, 273-294. [CrossRef]

47. Rose, R.; Haase, D.L.; Kroiher, F.; Sabin, T. Root volume and growth of ponderosa pine and Douglas-fir seedlings: A summary of eight growing seasons. West. J. Appl. For. 1997, 12, 69-73. [CrossRef]

48. Gonzalez-Orozco, M.M.; Prieto-Ruiz, J.A.; Aldrete, A.; Hernandez-Diaz, J.C.; Chavez-Simental, J.A.; Rodriguez-Laguna, R. Nursery production of Pinus engelmannii Carr. With substrates based on fresh sawdust. Forests 2018, 9, 678. [CrossRef]

49. Cicek, E.; Cicek, N.; Bilir, N. Effects of seedbed density on one-year-old Fraxinus angustifolia seedling characteristics and outplanting performance. New For. 2007, 33, 81-91. [CrossRef]

50. Popescu, I.; Popescu, S. Mecanizarea Lucrărilor Silvice; Transilvania University Press: Brașov, România, 2000; p. 533. ISBN 973-9474-53-5.

51. Braunack, M.V.; Dexter, A.R. Soil aggregation in the seedbed: A review. II. Effect of aggregate sizes on plant growth. Soil Tillage Res. 1989, 14, 281-298. [CrossRef]

52. Cubera, E.; Moreno, G.; Solla, A. Quercus ilex root growth in response to heterogeneous conditions of soil bulk density and soil NH4-N content. Soil Tillage Res. 2009, 103, 16-22. [CrossRef]

53. Taylor, H.M.; Brar, G.S. Effect of soil compaction on root development. Soil Tillage Res. 1991, 19, 111-119. [CrossRef]

54. Atkinson, B.S.; Sparkes, D.L.; Mooney, S.J. Effect of seedbed cultivation and soil macrostructure on the establishment of winter wheat (Triticum aestivum). Soil Tillage Res. 2009, 103, 291-301. [CrossRef]

55. Oprea, I. Tehnologia Exploatării Lemnului; Transilvania University Press: Brasov, Romania, 2008; p. 273. ISBN 978-973-598-301-7.

56. Radu, S.; Contescu, L.; Herta, I.; Burza, E.; Rosca, T. Pepiniere-Metode si Procedee Pentru Cultura in Pepiniera a Principalelor Specii Forestiere si Ornamentale—Recomandări Tehnice; Ministerul Apelor, Pădurilor şi Protecţiei Mediului, Regia Autonomă a Pădurilor Romsilva R.A.: Bucureşti, Romania, 1994; p. 134. 